\title{
Effect of eutrophication and humification on nutrient cycles and transfer efficiency of matter in freshwater food webs
}

\author{
Maciej Karpowicz (i) Piotr Zieliński • Magdalena Grabowska • \\ Jolanta Ejsmont-Karabin · Joanna Kozłowska • Irina Feniova
}

Received: 3 October 2019/Revised: 15 April 2020/Accepted: 21 April 2020/Published online: 27 April 2020

(C) The Author(s) 2020

\begin{abstract}
We evaluated how eutrophication and humification impacted nutrient cycles and the efficiency of carbon transfer in the planktonic food webs of 12 lakes in north-eastern Poland that differed in trophic state. Our results indicated that the effectiveness of carbon transfer between phytoplankton and zooplankton varied from $0.0005 \%$ to $0.14 \%$, which is much lower than the theoretical $10 \%$. The highest efficiency of carbon transfer occurred in the mesotrophic lakes due to the higher hypolimnetic zooplankton production, while the lowest efficiency was observed in the dystrophic lakes and in one eutrophic
\end{abstract}

Handling editor: Gideon Gal

M. Karpowicz ( $\square) \cdot$ M. Grabowska · J. Kozłowska Department of Hydrobiology, Faculty of Biology, University of Białystok, Ciołkowskiego 1J,

15-245 Białystok, Poland

e-mail: m.karpowicz@uwb.edu.pl

P. Zieliński

Department of Environmental Protection, Faculty of Biology, University of Białystok, Ciołkowskiego 1J, 15-245 Białystok, Poland

\section{J. Ejsmont-Karabin}

Research Station in Mikołajki, Nencki Institute of Experimental Biology, Polish Academy of Sciences, 3 Pasteur Street, 02-093 Warsaw, Poland

\section{Feniova}

Institute of Ecology and Evolution, Russian Academy of

Sciences, Leninsky Prospect 33, Moscow, Russia lake that was dominated by cyanobacteria. Inedible algae (e.g. Gonyostomum semen) and cyanobacteria appeared to be the main factors reducing the efficiency of the transfer of matter in pelagic food webs. The results of our study showed that plankton communities are a key component of the nutrient cycle in freshwater food webs. Phytoplankton were a very effective nitrogen sink, and in the mesotrophic lakes, up to $99 \%$ of the total nitrogen was sequestrated in phytoplankton. As a result, there was a depletion of inorganic nitrogen in the upper water layer. Furthermore, zooplankton were an important phosphorus sink, thus significantly influencing the nutrient cycles.

Keywords Stoichiometry · Plankton · Lakes · Trophic status · Carbon $\cdot$ Phosphorus and nitrogen

\section{Introduction}

Plankton communities are a key component in the ecosystems of freshwater lakes. Interactions between primary producers (phytoplankton or photoautotrophs) and primary consumers (zooplankton or heterotrophs) affect the overall functioning of freshwater ecosystems. Phytoplankton need a wide variety of chemical elements, but the two critical ones are nitrogen and phosphorous, as they often act as limiting factors (Vitousek \& Howarth, 1991). In the organic matter, the ratio of carbon, nitrogen, and phosphorus 
atoms is $106: 16: 1$, respectively. Most algae cannot use atmospheric nitrogen directly but, instead, acquire chemically reactive forms of this element, such as nitrate $\left(\mathrm{NO}_{3}{ }^{-}\right)$or ammonium $\left(\mathrm{NH}_{4}{ }^{+}\right)$. Similarly, algae use reactive forms of phosphorus $\left(\mathrm{PO}_{4}{ }^{3-}\right)$. Therefore, phytoplankton are an important link in the transformation of nutrients from inorganic to organic forms, thus reducing the amount of reactive nutrient forms. As a result, inorganic phosphorus is usually less than $5 \%$ of the total phosphorus (TP) in lakes (Boyd, 2015). The uptake of oxidized and reduced forms of nutrients can be separated in time and space due to their association with different phytoplankton groups ( $\mathrm{Yu}$ et al., 2018). Hence, changes in phytoplankton taxonomic structure and growth rates can affect their nutrient demand and uptake and, as such, can influence their carbon: nutrient stoichiometry (Sterner \& Elser, 2002). Therefore, the nutrient cycles can depend on phytoplankton community structures.

Zooplankton act as vectors transferring energy and matter from primary producers to higher trophic levels and play a central role in the biogeochemical cycles. One of the pivotal paradigms of ecology is that only about $10 \%$ of organic carbon production of one trophic level is incorporated into new biomass of organisms of the next trophic level (Gladyshev et al., 2011). However, there are large discrepancies in the effectiveness of the transfer of matter between lakes with different trophic statuses. In oligotrophic systems, the energy transfer efficiency between phyto- and zooplankton commonly varies in the range of ca. 5-30\% (Lacroix et al., 1999), and for higher trophic levels in pelagic food webs, it is around 10\% (Schulz et al., 2004). However, hypereutrophic lakes usually have a very high primary production with relatively little zooplankton and fish production (Brett \& MüllerNavarra, 1997) due to cyanobacterial blooms and the dominance of large inedible algae. Cyanobacteria are a poor food resource for zooplankton, which negatively influences large-bodied zooplankton through feeding interference, poor nutritional quality, and the production of toxins (Vanni \& Lampert, 1992; FerrãoFilho \& Kozlowsky-Suzuki, 2011). Thus, there is a shift in zooplankton communities to the domination of small species (rotifers and small cladocerans), which feed on other resources, like bacteria or picoplankton. As a result of the removal of small size classes of phytoplankton, colonial cyanobacteria grow more intensively (Haney, 1987), further deteriorating the water quality. However, it is not clear how differences in the phytoplankton and zooplankton structures affect the efficiency of carbon transfer in freshwater food webs. Nowadays, processes such as global warming and human activity intensify eutrophication in the freshwater lakes, resulting in a decrease in the efficiency of the transfer of matter and energy from phytoplankton to zooplankton. There are some evidences which suggest that efficient systems can support 25 times more biomass of zooplankton than inefficient eutrophic systems (Brett \& MüllerNavarra, 1997), and this could significantly affect the nutrient cycles in the pelagic food web.

The main aim of our study is to assess the contribution of zooplankton and phytoplankton as sinks of phosphorus and nitrogen in lakes with different trophic conditions. We hypothesize that (i) the efficiency of carbon transfer from phytoplankton to zooplankton will decrease with the intensification of eutrophication and humification processes, (ii) efficiency of transfer of matter between phytoplankton and zooplankton will be associated with a reduction in inorganic nitrogen and phosphorus in the water, and (iii) under mesotrophic conditions most of the nitrogen and phosphorus will be accumulated in plankton communities. In addition, we aimed to find combinations of phytoplankton and zooplankton structures, which provide efficient transfer of matter and energy within lake food webs. We also predict that differences in plankton communities will be related to differences in the elemental composition of zooplankton.

\section{Methods}

Study sites

The study was conducted in 12 lakes in north-eastern Poland with different morphometric parameters (Table 1) and different trophic statuses (Table 2) during the peak of summer stagnation (July 16-24, 2018). The sampling stations were located close to the deepest point of each lake. The maximum depth of the lakes ranged from 4 to 73 metres, and the surface area ranged from 0.96 to 2118.3 hectares (Table 1). The Carlson trophic state indexes (Carlson, 1977) of harmonic lakes ranged from 46.4 to 59.2, and the visibility of the Secchi disc (SDV) ranged from 1.1 to 
Table 1 Morphometric characteristics of the lakes

\begin{tabular}{llllllrrrr}
\hline No. & Lakes & Latitude & Longitude & $\begin{array}{l}\text { Area } \\
\text { (ha) }\end{array}$ & $\begin{array}{l}\text { Max } \\
\text { depth (m) }\end{array}$ & $\begin{array}{l}\text { Avg. } \\
\text { depth (m) }\end{array}$ & $\begin{array}{l}\text { V } \\
\left.\text { (thous. } \mathrm{m}^{3}\right)\end{array}$ & $\begin{array}{l}\text { Shor. } \\
\text { dev. }\end{array}$ & $\begin{array}{l}\text { Max } \\
\text { length (m) }\end{array}$ \\
\hline 1 & Białe Wigierskie & $54^{\circ} 01^{\prime} 57^{\prime \prime}$ & $23^{\circ} 05^{\prime} 41^{\prime \prime}$ & 100.2 & 34 & 13.2 & $13,193.5$ & 1.44 & 1875 \\
2 & Wigry & $54^{\circ} 00^{\prime} 51^{\prime \prime}$ & $23^{\circ} 03^{\prime} 45^{\prime \prime}$ & 2118.3 & 73 & 15.8 & $336,726.7$ & 4.43 & 17,500 \\
3 & Busznica & $53^{\circ} 56^{\prime} 38^{\prime \prime}$ & $23^{\circ} 05^{\prime} 00^{\prime \prime}$ & 49.4 & 48 & 6.8 & 3350.6 & 1.05 & 950 \\
4 & Okrągłe & $54^{\circ} 01^{\prime} 14^{\prime \prime}$ & $23^{\circ} 01^{\prime} 22^{\prime \prime}$ & 13.7 & 13 & 5.6 & 767.2 & 1.10 & 455 \\
5 & Długie Wigierskie & $54^{\circ} 01^{\prime} 17^{\prime \prime}$ & $23^{\circ} 02^{\prime} 03^{\prime \prime}$ & 80.0 & 14.8 & 6.4 & 5227.6 & 2.16 & 2075 \\
6 & Leszczewek & $54^{\circ} 04^{\prime} 18^{\prime \prime}$ & $23^{\circ} 03^{\prime} 50^{\prime \prime}$ & 21.0 & 6.5 & 3.6 & 755.3 & 1.51 & 1000 \\
7 & Garbaś & $54^{\circ} 07^{\prime} 44^{\prime \prime}$ & $22^{\circ} 37^{\prime} 42^{\prime \prime}$ & 152.5 & 48 & 20.9 & $31,809.7$ & 1.90 & 3450 \\
8 & Necko & $53^{\circ} 51^{\prime} 43^{\prime \prime}$ & $22^{\circ} 57^{\prime} 56^{\prime \prime}$ & 400.0 & 25 & 10.1 & $40,561.4$ & 1.84 & 5400 \\
9 & Wądołek & $54^{\circ} 07^{\prime} 44^{\prime \prime}$ & $23^{\circ} 04^{\prime} 02^{\prime \prime}$ & 1.1 & 15 & 8.9 & - & 1.05 & 155 \\
10 & Suchar I & $54^{\circ} 05^{\prime} 07^{\prime \prime}$ & $23^{\circ} 00^{\prime} 54^{\prime \prime}$ & 0.9 & 4 & 2.3 & - & 1.22 & 170 \\
11 & Suchar II & $54^{\circ} 05^{\prime} 15^{\prime \prime}$ & $23^{\circ} 01^{\prime} 04^{\prime \prime}$ & 2.5 & 10 & 4.6 & - & 1.06 & 209 \\
12 & Suchar Wielki & $54^{\circ} 01^{\prime} 40^{\prime \prime}$ & $23^{\circ} 03^{\prime} 22^{\prime \prime}$ & 8.9 & 9.6 & 3.9 & - & 1.68 & 760 \\
\hline
\end{tabular}

shor. dev. shoreline development, avg. average, - it means no data available

6.6 metres (Table 2). The humic lakes were characterized by highly dystrophic conditions with hydrochemical dystrophy indexes (HDI) ranging from 66.5 to 69.4 (Table 2). The dystrophic lakes were midforest and small, usually oval (Table 1), without any inflows or outflows (Górniak, 2017). Mesotrophic lakes were generally large and deep (Table 1) and their catchment area was dominated by forests. Among them, Lake Wigry (no. 2) stands out because it is one of the deepest and largest lakes in Poland, characterized by a very diversified morphometry and developed shoreline (Table 1). The eutrophic lakes had large agricultural catchment, were more diverse, varying from small and shallow lakes, e.g. Lake Leszczewek and Lake Okrągłe, to large and deep lakes, e.g. Lake Necko and Garbaś (Table 1). Most of the lakes are located in the Wigry National Park, with the exception of Lake Busznica, Lake Garbaś, and Lake Necko (East Suwałki Lakeland).

Physical and chemical parameters of the water and elemental analyses of seston and zooplankton

The field measurements included the Secchi disc visibility (SDV), electrical conductivity (EC), $\mathrm{pH}$, and the concentration of dissolved oxygen (DO), which was measured using an HQ40D Multi Meter (HachLange $\mathrm{GmbH}$ ). Phytoplankton (green algae, cyanobacteria, diatoms, cryptophytes, and the total chlorophyll $a$ concentration) and temperature were both measured in situ with the submersible spectrofluorometer FluoroProbe (bbe-Moldaenke). Changes in the resulting chlorophyll emission provide fluorometric estimation of algal classes based on differences in class-dependent peripheral antenna pigments (Beutler et al., 2002). The FluoroProbe determines the four distinct phytoplankton classes: green algae (Chlorophyceae and Euglenophyceae), cyanobacteria (phycocyanin- rich Cyanobacteria), diatoms (Heterokontophyta, Haptophyceae, and Dinophyceae) and cryptophytes (Cryptophyta and the phycoerythrinrich Cyanobacteria). The Chlorophyceae have a broad maximum of fluorescence at $470 \mathrm{~nm}$, which is caused by chlorophyll $a$ and $b$. The Cyanobacteria has a maximum at $610 \mathrm{~nm}$ due to the phycocyanin. Cyanobacteria also contain chlorophyll $a$ whose intensity of fluorescence is observed at $470 \mathrm{~nm}$, due to the masking effect from phycocyanin. Furthermore, the high peak at the $525 \mathrm{~nm}$ wavelength is originated from xanthophyll fucoxanthin for the Bacillariophyceae and peridin for the Dinophyceae. Due to the presence of phycoerythrin, the Cryptophyceae have a significant fluorescence maximum at $570 \mathrm{~nm}$ (Kring et al., 2014; Karpowicz \& Ejsmont-Karabin, 2018). Continuous measurements of phytoplankton by probe represent a great advantage over discrete sampling since some species of phytoplankton can be concentrated in a very thin layer (Gregor \& Maršálek, 2004). In situ measurements of the chlorophyll $a$ concentrations were used to calculate the gross primary 
Table 2 Trophic characteristic of lakes (July 2018)

\begin{tabular}{|c|c|c|c|c|c|c|c|c|c|}
\hline No. & Lakes & TSI $^{*}$ & $\mathrm{HDI}^{* * *}$ & $\begin{array}{l}\text { Trophic } \\
\text { status }\end{array}$ & SDV (m) & PZ (m) & $\begin{array}{l}\text { Thermocline } \\
\text { depth (m) }\end{array}$ & chl $a$ epi & chl $a$ meta \\
\hline 1 & Białe Wigierskie & 46.4 & 19.2 & Mesotrophic & 5.7 & 14.5 & $6.5-11.0$ & $2.3 \pm 0.6$ & $1.9 \pm 0.1$ \\
\hline 2 & Wigry & 47.3 & 15.9 & Mesotrophic & 5.2 & 10.5 & $7.5-10.0$ & $3.8 \pm 1.1$ & $3.1 \pm 1.0$ \\
\hline 3 & Busznica & 47.3 & 26.1 & Mesotrophic & 6.6 & 8.5 & $4-10.0$ & $4.5 \pm 1.0$ & $4.8 \pm 0.8$ \\
\hline 4 & Okrągłe & 50.9 & 16.7 & Eutrophic & 3.1 & 7.5 & $3.5-8.0$ & $4.6 \pm 1.4$ & $6.3 \pm 2.0$ \\
\hline 5 & Długie Wigierskie & 54.1 & 22.3 & Eutrophic & 1.65 & 7.0 & $4.0-8.0$ & $6.9 \pm 1.8$ & $22.8 \pm 18.3$ \\
\hline 6 & Leszczewek & 56.2 & 19.4 & Eutrophic & 2.3 & 5.0 & $>3.0$ & $12.2 \pm 4.2$ & $94.8 \pm 48.8$ \\
\hline 7 & Garbaś & 57.9 & 16.1 & Eutrophic & 2.0 & 5.0 & $4.0-9.0$ & $26.2 \pm 5.5$ & $34.5 \pm 21.3$ \\
\hline 8 & Necko & 59.2 & 19.5 & Eutrophic & 1.1 & 5.0 & $4.5-10$ & $15.5 \pm 3.8$ & $3.9 \pm 1.8$ \\
\hline 9 & Wądołek & 67.7 & 68.6 & Dystrophic & 1.2 & 4.0 & $1.0-3.0$ & $21.1 \pm 3.5$ & $61.9 \pm 32.2$ \\
\hline 10 & Suchar I & 61.9 & 66.5 & Dystrophic & 1.1 & 2.0 & $1.2-4.0$ & $27.1 \pm 0.9$ & $109.0 \pm 45.6$ \\
\hline 11 & Suchar II & 53.9 & 69.4 & Dystrophic & 1.9 & 3.5 & $1.5-5.5$ & $9.2 \pm 2.0$ & $49.3 \pm 29.9$ \\
\hline 12 & Suchar Wielki & 55.8 & 68.2 & Dystrophic & 2.2 & 4.7 & $3.2-6.0$ & $26.0 \pm 3.1$ & $61.0 \pm 24.4$ \\
\hline
\end{tabular}

TSI trophic state index (Carlson 1977), HDI hydrochemical dystrophy index (Górniak 2017), SDV Secchi disc visibility, PZ photic zone, epi epilimnion, meta metalimnion

$* \mathrm{TSI}=[\mathrm{TSI}(\mathrm{SDV})+\mathrm{TSI}(\mathrm{chla})+\mathrm{TSI}(\mathrm{TP})] / 3 ; \quad \operatorname{TSI}(\mathrm{SDV})=60 \quad-\quad 14.41 \quad \ln (\mathrm{SDV}) ; \quad \mathrm{TSI}(\mathrm{chla})=9.81 \quad \ln (\mathrm{chla})+30.6 ;$ $\mathrm{TSI}(\mathrm{TP})=14.42 \ln (\mathrm{TP})+4.15$

$* * \mathrm{HDI}=\mathrm{HDI}_{1}+\mathrm{HDI}_{2}+\mathrm{HDI}_{3} / 3 ; \mathrm{HDI}_{1}=20(9.5-\mathrm{pH}) ; \mathrm{HDI}_{2}=100 / \log (\mathrm{EC}) ; \mathrm{HDI}_{3}=10 \mathrm{DOC} / \mathrm{DIC}$

production (GPP) and enriched taxonomic identification of algae (described below). Field measurements of temperature, oxygen, conductivity, $\mathrm{pH}$, and phytoplankton were made from the surface to a depth of 30 metres.

Chemical analyses of the water samples were conducted in the laboratory immediately after collection. The concentrations of ions $\left(\mathrm{PO}_{4}{ }^{3-}, \mathrm{NH}_{4}{ }^{+}, \mathrm{NO}_{3}{ }^{-}\right.$, $\mathrm{NO}_{2}{ }^{-}$) were determined using a Dionex ICS 1100 ion chromatograph. The concentrations of total nitrogen (TN), dissolved organic carbon (DOC), dissolved inorganic carbon (DIC), and total carbon (TC) were analysed by high-temperature catalytic combustion in the Shimadzu TOC-L Series analysers. TP analyses were conducted according to the conventional photocolorimetric method (Murphy \& Riley, 1962), modified by Neal et al. (2000).

We also collected samples of seston $(<100 \mu \mathrm{m})$ and zooplankton $(>100 \mu \mathrm{m})$ from every lake for elemental analysis. The seston represents all particles and live organisms (phytoplankton, small rotifers, and bacteria) that passed through a net with $100 \mu \mathrm{m}$ mesh. However, in freshwater lakes, the main component of seston is usually phytoplankton (Feniova et al., 2019).
For the seston samples, we collected $0.5-1.01$ of water from different water layers (epilimnion, metalimnion, and hypolimnion) in each lake. Subsequently, we filtered them through pre-combusted glass-fibre $\mathrm{GF} / \mathrm{F}$ filters (Whatman, USA). The zooplankton samples were collected by vertical hauls and filtered on mesh sieves $(100 \mu \mathrm{m})$ and then placed on filter paper to remove the surface moisture. We kept filters for seston analyses at room temperature for $24 \mathrm{~h}$, while zooplankton samples were dried at $75^{\circ} \mathrm{C}$ overnight and stored dry in a desiccator until further analyses. The TC concentrations in seston and zooplankton were measured using Shimadzu TOC-L Series analysers with Solid Sample Modules SSM-5000A. TN was determined with Koroleff's photometric method using TN Cell Tests by Spectroquant, Merc (KGaA). Contents of TP analyses in seston and zooplankton were estimated following the conventional photocolorimetric method (Murphy \& Riley, 1962). In conclusion, we used similar methods to assess nutrient concentrations in water, seston, and zooplankton. We then determined the role of phytoplankton and zooplankton as nutrient sinks by comparing the concentrations of nitrogen and phosphorus in 
phytoplankton and zooplankton to the total amount of nutrients in the water.

\section{Plankton analyses}

The 101 samples for taxonomical analyses of zooplankton and phytoplankton were taken from the epilimnion, metalimnion, and hypolimnion in each lake with a 51 Limnos sampler. The zooplankton samples were filtered through a $50 \mu \mathrm{m}$ mesh sieve and fixed with $4 \%$ formaldehyde. Rotifers and crustacean species were identified and counted in the whole samples. Additionally, the lengths of 10 individuals of each species were measured. Mean animal lengths were used to estimate the wet weight of planktonic crustaceans by applying the equations after Błędzki \& Rybak (2016). The biomass of rotifers was established following length-weight relationships in EjsmontKarabin (1998). Cladocerans were further divided into large (Daphnia spp. and Diaphanosoma spp.) and small species (Ceriodaphnia spp., Bosmina spp., Chydorus sphaericus (O.F. Müller, 1776), etc.) because body size is an important attribute of cladoceran functional biology and ecology (Hart \& Bychek, 2011), and small- and large-bodied cladocerans respond differently to predation pressure and algal abundance (Feniova et al., 2018; Karpowicz et al., 2019b).

Water samples for phytoplankton analysis were fixed with Lugol's solution. Phytoplankton abundance was determined according to the Utermöhl method (Utermöhl, 1958). Cells, colony, and filaments with a length of $100 \mu \mathrm{m}$ were counted. The biomass of the phytoplankton species was determined based on cell sizes and their approximations to simple geometric shapes (Hillebrand et al., 1999).

Primary and secondary production of plankton

The GPP was estimated by the chlorophyll fluorescence method with DCMU (3-(3,4-dichlorophenyl)1,1-dimethylurea), as described by the Gaevsky et al. (2000). We measured, in situ, the vertical distribution of phytoplankton, and in the laboratory, we estimated the potential photochemical activity of photosystem II for different groups of algae with DCMU using the FluoroProbe with Workstation 25. The DCMU was added to the samples to inhibit the reoxidation of the reduced primary electron acceptor $(\mathrm{Q})$ of photosystem
II, yielding maximum fluorescence (Ishimaru et al., 1985). The GPP $\left(\mathrm{gO}_{2} \mathrm{l}^{-1} \mathrm{~h}^{-1}\right)$ was calculated by the empirical equation (Gaevsky et al., 2000) for phytoplankton:

$\mathrm{GPP}=b F_{\mathrm{v}} / F_{\mathrm{m}} \mathrm{Chl} a \mathrm{I}$,

where $b$ is the empirical coefficient, $0.00042, F_{\mathrm{v}} / F_{\mathrm{m}}$ is the relative variable fluorescence (arb.units), $\mathrm{Chl} a$ describes the chlorophyll $a$ concentration of algae ( $\mu \mathrm{g}$ $1^{-1}$ ), and $I$ is the average intensity of photosynthetically active radiation (PAR, $\mathrm{W} \mathrm{m}^{-2}$ ). Relative variable fluorescence was calculated by the following formula:

$F_{\mathrm{v}} / F_{\mathrm{m}}=\left(F_{\mathrm{m}} / F_{0}\right) / F_{\mathrm{m}}$,

where $F_{0}$ is the steady-state level of fluorescence and $F_{\mathrm{m}}$ describes the maximum level after the addition of $10 \mu \mathrm{M}$ DCMU. The relative variable fluorescence summarizes the general condition of alga cells and their instant photosynthetic capacity.

GPP per hour was multiplied by daylight hours (using https://www.timeanddate.com/) for daily GPP calculations. In situ attenuation of PAR $\left(\mathrm{W} \mathrm{m}^{-2}\right)$ was measured with a portable underwater irradiance metre with a Licor radiation sensor, LI-193SA Spectral Quantum sensor (USA). The conversion factor for GPP from $\mathrm{mg} \mathrm{O}_{2}$ to $\mathrm{mg} \mathrm{C}$ was 0.32 (Alimov, 1989).

The production of zooplankton (secondary production) was calculated using regression models from Stockwell \& Johansson (1997):

$P=10^{(-0.23 \log (M)-0.73)} 1.12 M N$,

where $P$ is the daily production $\left(\mu \mathrm{g} \mathrm{DW} l^{-1}\right.$ day $^{-1}$ ), $M$ is the mean individual dry weight $(\mu \mathrm{g})$, and $N$ is the abundance (individuals $1^{-1}$ ).

Small rotifers from the seston subsamples were also included in zooplankton production estimations. Production of rotifer communities was established from the number of eggs counted in the samples. A curvilinear logarithmic generalized relationship between the rate of egg development and the temperature was used (Bottrell et al., 1976). Dry weight was converted into carbon units using a 1/2.3 quotient (Alimov, 1989).

The trophic transfer efficiency between the two trophic levels, phytoplankton (primary producers) and zooplankton (consumers), was calculated as the percentage ratio between the primary production and the 
secondary (zooplankton) production in the whole water column (Gladyshev et al., 2011).

\section{Statistical analyses}

We used a one-way analysis of variance (ANOVA) with type III sums of squares (SS) to determine how the analysed parameters (zooplankton communities, the elemental composition of plankton, primary and secondary production, and the effectiveness of carbon transfer) differed between the trophic conditions. If significant treatment effects were detected, we used the Tukey HSD (Honestly Significantly Different) post hoc test $(P<0.05)$ to determine which means differed. To analyse the differences between the trophic levels, plankton production, and the effectiveness of carbon transfer, we used ANOVA with the least-squares means (LS). To test the importance of environmental parameters on zooplankton communities, we used the ANOVA with type III SS, and then, we used those parameters as factors in the multivariate analysis. Canonical correspondence analysis (CCA) was performed to find combinations of abiotic (nitrogen forms, TP, DO, and trophic status) and biotic (groups of phytoplankton based on $\mathrm{Chl} a$ ) factors affecting the community structure of zooplankton.

\section{Results}

Hydrochemistry

The EC of the studied lakes in the eutrophic lakes group exceeded $400 \mu \mathrm{S} \mathrm{cm}^{-1}$, and in the mesotrophic lakes group, it was close to $250 \mu \mathrm{S} \mathrm{cm}^{-1}$. In the case of dystrophic lakes, it did not exceed $30 \mu \mathrm{S} \mathrm{cm}-1$ (Table 3). The dystrophic lakes were distinguished by low $\mathrm{pH}$ values and high DOC concentrations (Table 3), while harmonic lakes had much more DIC (Table 3). The vertical profiles of DO in the eutrophic and dystrophic lakes were clinograde type, and in dystrophic lakes, oxygen depletion was just below the epilimnion (Table 3) at a depth of 2-3 metres. The mesotrophic lakes were characterized by the orthograde oxygen profile, with a well-oxygenated hypolimnion. The harmonic lakes had a higher concentration of nutrients in the lower water layers, especially those available for phytoplankton. The concentration of nitrates $\left(\mathrm{NO}_{3}{ }^{-}\right)$in the hypolimnion was even 180 times higher than in the epilimnion of mesotrophic lakes (Table 3). The smallest differences between the investigated lake types were recorded for TN (Table 3).

Phytoplankton communities

The maximum concentration of chlorophyll $a$ in the mesotrophic lakes was $5.89 \mu \mathrm{g}^{-1}$, while in the eutrophic and dystrophic lakes it was $144.72 \mu \mathrm{g} 1^{-1}$ and $143.75 \mu \mathrm{g}^{-1}$, respectively. The most eutrophic and dystrophic lakes had maximum concentrations of phytoplankton in the thermocline, while in the mesotrophic lakes, there were similar $\mathrm{Chl} a$ concentrations in the epilimnion and metalimnion (Table 2). The dominant group in the dystrophic lakes was green algae, which contributed to more than $60 \%$ of the total phytoplankton biomass (Fig. 1). The high share of green algae was also observed in most of the eutrophic lakes. Cyanobacteria dominated below the epilimnion in lake no. 5 and in the hypolimnion in lake no. 2. The dominant groups of phytoplankton in mesotrophic lakes were diatoms and cryptophytes (Fig. 1).

Microscopic analysis of the phytoplankton biomass (PB) of the three mesotrophic lakes indicated the dominance or co-dominance of Dinophyceae (48.9-96.5\% of the PB in lake no. 2, $24.6 \%$ of the $\mathrm{PB}$ in the epilimnion of lake no.1) and Chlorophyceae (28.6\% of the PB in lake no. 2, 62.8-65.2\% of the PB in lake no. 3). Dinophyceae were represented mainly by Ceratium hirundinella (O.F.Müller) Dujardin, 1841; Peridinium cinctum Ehrenberg, 1838; and Peridinium spp., while Chlorophyceae was represented by Phacotus lenticularis (Ehrenberg) Diesing, 1866 (lake no. 2), Dictyosphaerium sp., and Botryococcus braunii Kützing, 1849 (lake no. 3, Table 4).

The main component of phytoplankton in the three eutrophic lakes (no. 4, 6, 8) were Chlorophyceae from the order Chlorococcales, which reached, respectively, 72-90\%, 55.8-72.4\%, and 33.7-55.2\% of the PB. They were represented mainly by $P$. lenticularis (all lakes), Coelastrum polychordum (Korshikov) Hindák, 1977 (lake no. 8), and Oocystis spp., Tetraedron minimum (A.Braun) Hansgirg, 1888; Tetrastrum komarekii Hindák, 1977 (Table 4). In the case of lake no. 5, Chlorococcales (45.2\%), represented mainly by $P$. lenticularis and Dictyosphaerium sp., co-dominated with Dinophyceae $(38.3 \%$, C. hirundinella) only in epilimnion. However, in the deeper layers, 


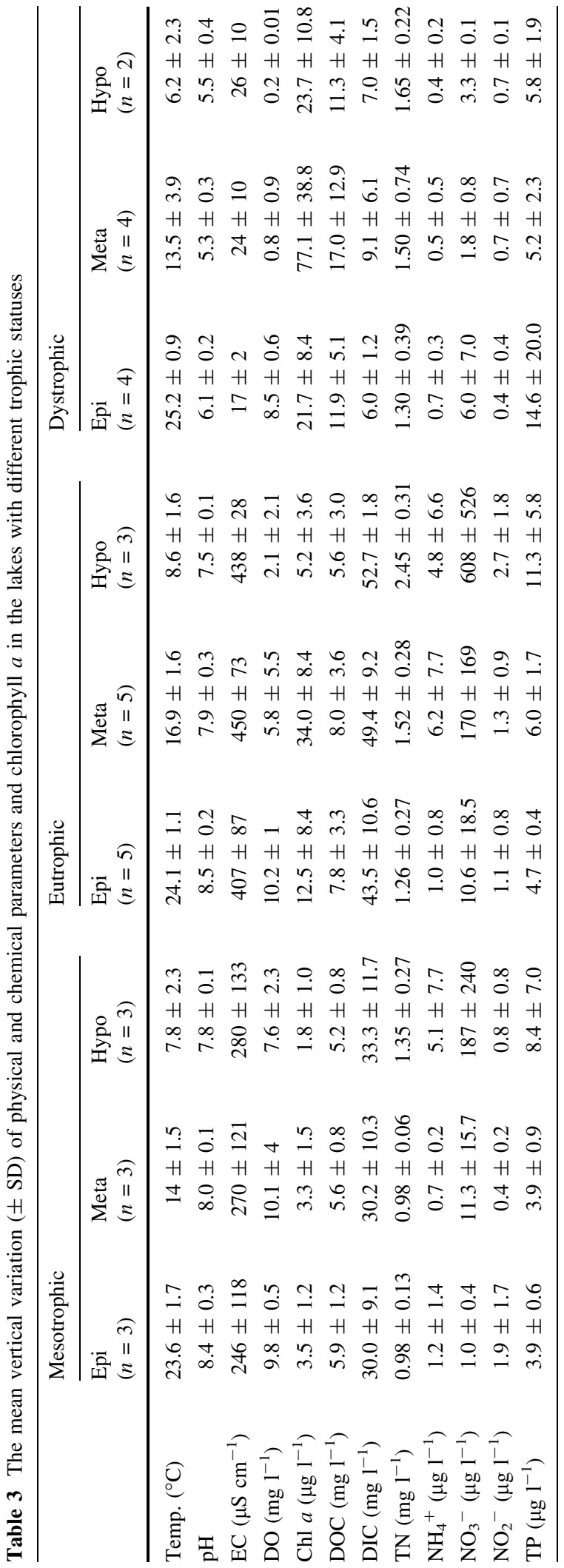

cyanobacteria (Aphanizomenon sp.) created $57.9-79.4 \%$ of the PB. The reverse situation was observed in lake no. 6, where the highest share of Chlorococcales (P. lenticularis) was recorded in the hypolimnion, while in the epi- and metalimnion, $C$. hirundinella was clearly dominant (81.3-91.7\% of the PB).

Raphidophytes Gonyostomum semen (Ehrenberg) Diensig, 1866 reached the highest share in the three dystrophic lakes. The contribution of this species in the PB fluctuated between 67.7 and $92.7 \%$ (lake no. 9), 64.7-84.8\% (lake no. 10), and 43.4-64.7 (lake no. 11). The predominance of Dinophyceae (45.6-80\% of the PB), represented by Gymnodinium sp. and Peridinium sp., over Chlorophyceae (10.7-17.2\% of the PB) was observed only in lake no. 12. The most numerous species were Quadrigulla closteroides (Bohlin) Printz, 1915 and Raphidophyceae (5.33-14.3\%) (Table 4).

\section{Zooplankton communities}

In the mesotrophic lakes, the biomass of zooplankton ranged from 0.53 to $3.77 \mathrm{mg} \mathrm{l}^{-1}$ (Fig. 2) and averaged $2.08 \mathrm{mg}^{-1}$. The mesotrophic lakes are characterized by the greatest diversity of planktonic crustaceans, and the number of species ranged from 14 to 15 . Rare and relict species were also detected: Eurytemora lacustris (Poppe, 1887) in lakes no. 1 and 2, Heterocope appendiculata Sars G.O., 1863 in lakes no. 1 and 3, Cyclops lacustris Sars G.O., 1862 in lake no. 1, Bythotrephes brevimanus Lilljeborg, 1901 in lake no.3, and Daphnia longiremis G.O. Sars, 1861 in lakes no.1 and 2. There was a large diversity of the Daphnia genus in lakes no.1 and 2, where four species were found. Besides the dominant Daphnia cucullata G.O. Sars, 1862 (Table 5), which contributed $65 \%$ of the total crustacean biomass in the mesotrophic lakes, we found Daphnia cristata G.O. Sars, 1862; Daphnia longispina (O.F. Müller, 1776) and D. longiremis. The genus Bosmina was also represented by 3 to 4 species in the mesotrophic and eutrophic lakes (Table 5). Large cladoceran species dominated in the zooplankton communities of lakes no. 2, 3, and 4 (Fig. 2), while the cyclopoid group comprised the highest share in lake no.1 (Fig. 2), with the 


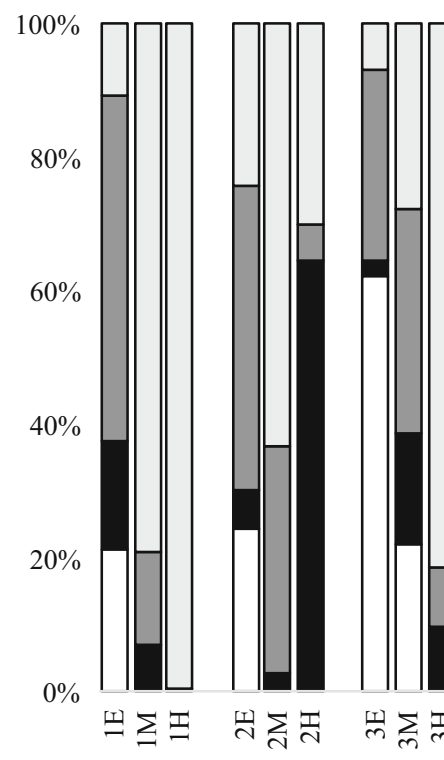

MESOTROPHIC

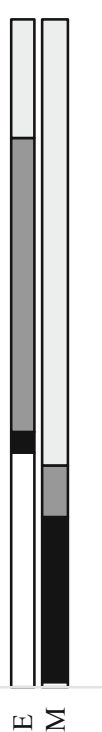

装导

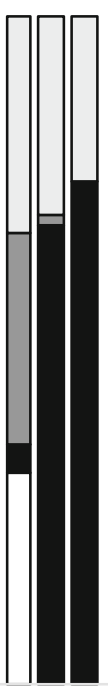

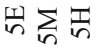

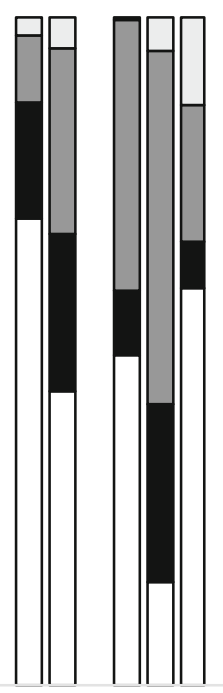

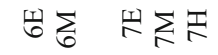
EUTROPHIC
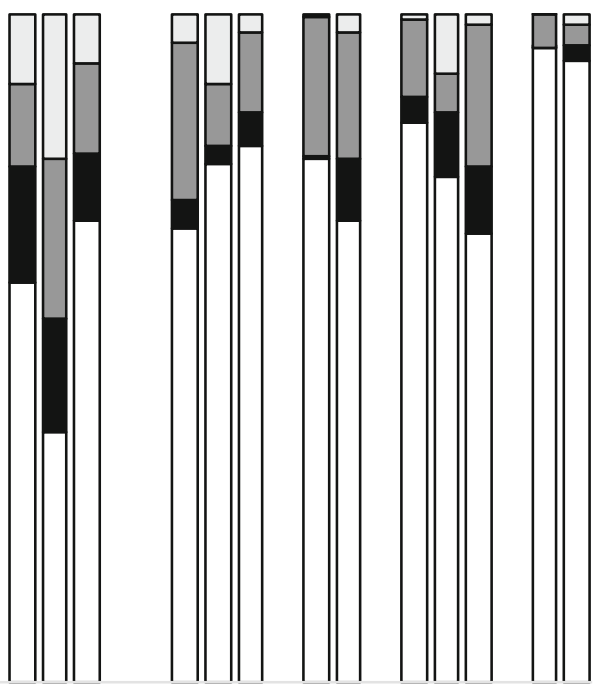

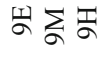

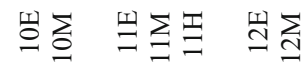
DYSTROPHIC

$\square$ green $\square$ cyanobacteria $\square$ diatoms $\square$ cryptophytes

Fig. 1 The percentage share of main phytoplankton groups. Numbers 1-12 correspond to the lakes (Tables 1 and 2); $E$ epilimnion, $M$ metalimnion, $H$ hypolimnion

domination of Cyclops scutifer Sars G.O., 1863 and relict $C$. lacustris (Table 5). Rotifer biomass in the mesotrophic lakes was relatively low, except for in the hypolimnion of lake no. 2, where the total rotifer biomass reached $0.35 \mathrm{mg}^{-1}$ in the epilimnion due to the mass development of the colonial species Conochilus hippocrepis (Schrank, 1803) (Table 5). In the other lakes, rotifer biomass in the epilimnion was very low, i.e. $0.01-0.05 \mathrm{mg} \mathrm{l}^{-1}$. The other abundant rotifer species was Keratella cochlearis Gosse, 1851, which was especially dense in deep zones where its macracantha form was characterized by markedly higher body size.

In the eutrophic lakes, the biomass of zooplankton varied from 0.53 to $7.71 \mathrm{mg} \mathrm{l}^{-1}$ (Fig. 2), with an average of $3.39 \mathrm{mg} \mathrm{l}^{-1}$. The species richness of the crustaceans in the eutrophic lakes ranged from 9 to 14 , and the relic Eurytemora lacustris was found in one eutrophic lake (no. 7). In lakes no. 4 and 5, zooplankton was dominated by large Cladocera (mostly $D$. cucullata and Diaphanosoma brachyurum (Liévin, 1848)), while in the other eutrophic lakes, the shares of the main zooplankton groups were similar (Fig. 2). The highest contribution to the rotifer biomass in eutrophic lakes was made by the large predatory rotifer, Asplanchna priodonta Gosse, 1850. This rotifer species was most abundant in the metalimnion of lakes no. 4, 6, and 7 and in the meta- and hypolimnion of lake no. 5 . The other abundant rotifer species in all eutrophic lakes were Gastropus stylifer Imhof, 1891; K. cochlearis, Pompholyx sulcata Hudson, 1885, and 3 species of the genus Polyarthra (Table 5).

The biomass of zooplankton in the dystrophic lakes ranged from 0.015 to $3.25 \mathrm{mg}^{-1}$ (Fig. 2), averaging $0.67 \mathrm{mg} \mathrm{l}^{-1}$. The number of crustacean species in the dystrophic lakes ranged from 3 to 6 . The dominant crustacean species was Ceriodaphnia quadrangula (O.F. Müller, 1785), which contributed up to $93 \%$ to the total crustacean biomass in lake no. 12. The calanoid copepod Eudiaptomus gracilis (Sars G.O., 1863) was found in all the dystrophic lakes (Table 5) and made up to $75 \%$ of the total crustacean biomass in the lake no. 11 (Fig. 2). Rotifers in dystrophic lakes were represented by Conochiloides dossuarius (Hudson, 1885); Polyarthra remata Skorikov, 1896; K. cochlearis, and A. priodonta (Table 5); however, these species occurred in various combinations. $C$. dossuarius and $P$. remata dominated in lake no. 11 (ca. $84 \%$ of the total rotifer biomass) and lake no. 10 (ca. 
Table 4 The list of the dominant phytoplankton species (more than 5\% of total biomass) in 12 lakes

\begin{tabular}{|c|c|c|c|c|c|c|c|c|c|c|c|c|}
\hline & 1 & 2 & 3 & 4 & 5 & 6 & 7 & 8 & 9 & 10 & 11 & 12 \\
\hline \multicolumn{13}{|l|}{ Cyanophyceae } \\
\hline Aphanizomenon sp. & & & & & $* * *$ & & & & & & & \\
\hline $\begin{array}{l}\text { Dolichospermum lemmermannii (Richter) P.Wacklin, } \\
\text { L.Hoffmann \& J.Komárek, } 2009\end{array}$ & $* *$ & & & & & & & & & & & \\
\hline \multicolumn{13}{|l|}{ Euglenophyceae } \\
\hline Trachelomonas volvocina Ehrenberg var. volvocina & $*$ & & & & & & & & & & & \\
\hline \multicolumn{13}{|l|}{ Dinophyceae } \\
\hline Ceratium furcoides (Levander) Langhans, 1925 & & & & & & & $*$ & & & & & \\
\hline Ceratium hirundinella (O.F.Müller) Dujardin, 1841 & & $* * *$ & $*$ & $* *$ & $* *$ & & $* * *$ & & & & & \\
\hline Gymnodinium fuscum (Ehrenberg) Stein, 1978 & & & & & & & & & & & $* *$ & \\
\hline Gymnodinium sp. & & & $*$ & & & & & & & & & *** \\
\hline Peridiniopsis cunningtonii Lemmerman, 1907 & & & & $*$ & & $* *$ & & & & & & \\
\hline Peridinium cinctum Ehrenberg, 1838 & & $*$ & & $* *$ & & & & & & & & \\
\hline Peridinium gatunense Nygaard, 1925 & & & & $*$ & & & & & & & & \\
\hline Peridinium inconspicuum Lemmerman, 1899 & $* *$ & & & & & & & & $*$ & $* *$ & & $*$ \\
\hline Peridinium sp. & & & & & & & & & & & & $*$ \\
\hline \multicolumn{13}{|l|}{ Cryptophyceae } \\
\hline Cryptomonas spp. & & & $*$ & * & $* *$ & & & $*$ & $*$ & * & $* *$ & \\
\hline \multicolumn{13}{|l|}{ Chrysophyceae } \\
\hline Chromulina sp. & & & & & & & & & & & & $*$ \\
\hline \multicolumn{13}{|l|}{ Raphidophyceae } \\
\hline Gonyostomum semen (Ehrenberg) Diensig, 1866 & & & & & & & & & $* * *$ & $* *$ & $* *$ & $*$ \\
\hline \multicolumn{13}{|l|}{ Bacillariophyceae } \\
\hline Fragilaria crotonensis Kitton, 1869 & & $*$ & & & & & & & & & & \\
\hline Tabellaria fenestrata (Lyngbye) Kützing, 1844 & & & & & & & $* *$ & & & & & \\
\hline \multicolumn{13}{|l|}{ Chlorophyceae } \\
\hline Botryococcus braunii Kützing, 1849 & & & $* *$ & & & & & & & & & \\
\hline Coelastrum polychordum (Korshikov) Hindák, 1977 & & & & & & & & $* *$ & & & & \\
\hline Crucigeniella fenestrata (Schmidle) Schmidle, 1900 & & & & & & & & & & & $*$ & \\
\hline Dictyosphaerium sp. & & & $* *$ & & * & & & & & $* *$ & & \\
\hline Oocystis spp. & $* *$ & & $*$ & * & & $*$ & & & & & & \\
\hline Phacotus lenticularis (Ehrenberg) Diesing, 1866 & & $*$ & & $* *$ & * & $* *$ & $* *$ & $* *$ & & & & \\
\hline Tetraedron minimum (A.Braun) Hansgirg, 1888 & & & & & & $*$ & & & & & & \\
\hline Tetrastrum komarekii Hindák, 1977 & & & & & & $*$ & & & & & & \\
\hline Unicellular Chlorococcales & & & & & & $* *$ & & & & & $* *$ & \\
\hline Quadrigulla closteroides (Bohlin) Printz, 1915 & & & & & & & & & & & & $* *$ \\
\hline
\end{tabular}

*For species with biomass $5-10 \%$

**For species constituting $10-50 \%$ of the biomass

$* * *$ For species with biomass $>50 \%$ of total phytoplankton biomass

76\%). Further both these species, together with $A$. priodonta, were observed in lake no. 9, accounting for up to ca. $88 \%$ of the total rotifer biomass. A. priodonta, $K$. cochlearis, and $P$. remata dominated in lake no 12 .
There were significant differences in the biomasses of Rotifera $(F=5.59 ; P=0.009)$ and large Cladocera $(F=4.65 ; P=0.018)$ between the eutrophic and dystrophic lakes. There were also differences in the 


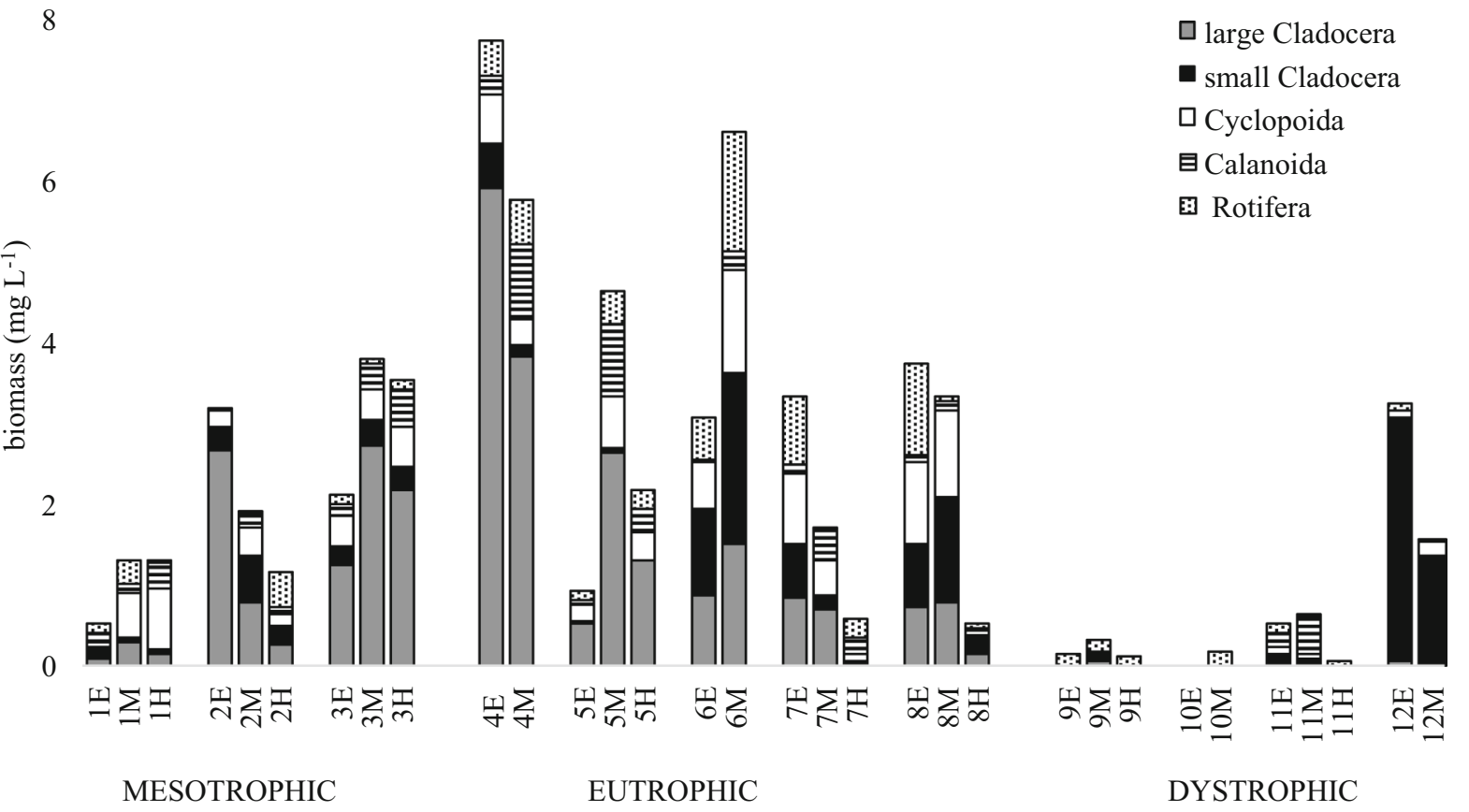

Fig. 2 Zooplankton biomass with a share of main zooplankton groups. Abbreviation as in Fig. 1

biomass of Cyclopoida between harmonic lakes (highest biomass) and dystrophic lakes (lowest biomass), while in the small bodied Cladocera and Calanoida, there were no significant differences in the biomasses between lakes with different trophic states. The CCA revealed that phytoplankton groups were the most important factor affecting the community structure of zooplankton. The Calanoida and large Cladocera could be positively linked with cryptophytes and diatoms while they were negatively linked with cyanobacteria and green algae (Fig. 3). On the contrary, small bodied Cladocera was related with a high abundance of cyanobacteria and green algae (Fig. 3). The CCA also clearly distinguished zooplankton communities in dystrophic lakes due to higher shares of small bodied Cladocera and Calanoida (Fig. 3).

\section{Elemental composition of zooplankton}

The dry weight of zooplankton was $7.8 \pm 1.4 \%$ of the wet weight. The content of carbon, nitrogen, and phosphorus in zooplankton was $52.4 \pm 6.4 \%$, $7 \pm 1.8 \%$, and $1.1 \pm 0.3 \%$, respectively. The carbon content in zooplankton showed the highest variability in the dystrophic lakes (Fig. 4A). The highest carbon content in zooplankton was found in lakes no. 10
$(66.3 \%)$ and no. $11(65.1 \%)$, where the zooplankton was mainly represented by Rotifera and Calanoida (Fig. 2). The lowest carbon content in zooplankton was found in lake no. $12(47.1 \%)$, where small cladocerans dominated (Fig. 2). The carbon content of zooplankton in the eutrophic and mesotrophic lakes was similar (Fig. 4A) and accounted for $49.9 \pm 1.6 \%$. There were no significant differences in nitrogen and phosphorus content in zooplankton between different trophic conditions (Fig. 4B, C). The analysis of variance revealed that differences in the community structure did not result in changes in the elemental composition of zooplankton. However, the type III SS test showed that Calanoida may be associated with a decrease in the amount of phosphorus in zooplankton $(F=3.78 ; \quad P=0.091)$, and large Cladocera were positively correlated with phosphorus content in zooplankton $(F=3.36 ; P=0.11)$.

Phytoplankton and zooplankton as a sink of nitrogen and phosphorus

The average nitrogen content in phytoplankton varied from $53 \%$ (dystrophic lakes) to $65 \%$ (eutrophic and mesotrophic lakes) of TN (Fig. 5C). However, in one mesotrophic lake, the phytoplankton nitrogen content 
Table 5 The list of the dominant zooplankton species (more than 5\% of total biomass) in 12 lakes

\begin{tabular}{|c|c|c|c|c|c|c|c|c|c|c|c|c|}
\hline & 1 & 2 & 3 & 4 & 5 & 6 & 7 & 8 & 9 & 10 & 11 & 12 \\
\hline \multicolumn{13}{|l|}{ Cladocera } \\
\hline Bosmina berolinensis Imhof, 1888 & & * & $*$ & $*$ & $*$ & $*$ & & $*$ & & & & \\
\hline Bosmina (Eubosmina) coregoni Baird, 1857 & $*$ & & $* *$ & $*$ & & & $*$ & $*$ & $* * *$ & $* *$ & & \\
\hline Bosmina (Eubosmina) crassicornis Lilljeborg, 1887 & $*$ & $* *$ & & * & $*$ & & $* *$ & $* *$ & & & & \\
\hline Bosmina longispina Leydig, 1860 & $*$ & * & $*$ & & $*$ & $*$ & $*$ & * & $*$ & & & \\
\hline Ceriodaphnia quadrangula (O.F. Müller, 1785) & & & $*$ & * & & $* *$ & & $* *$ & & & $* *$ & $* * *$ \\
\hline Chydorus sphaericus (O.F. Müller, 1776) & & & & * & & $*$ & & * & & & & \\
\hline Daphnia cristata G.O. Sars, 1862 & $*$ & * & & $*$ & & & & & & & & \\
\hline Daphnia cucullata G.O. Sars, 1862 & $* *$ & $* *$ & $* * *$ & $* * *$ & $* * *$ & $* *$ & $* *$ & $* *$ & $* *$ & $* *$ & & $*$ \\
\hline Daphnia longispina (O.F. Müller, 1776) & $*$ & $*$ & $*$ & $*$ & $*$ & & $*$ & $*$ & & & & $*$ \\
\hline Diaphanosoma brachyurum (Liévin, 1848) & $*$ & $*$ & $* *$ & $* *$ & $*$ & $*$ & $*$ & * & $*$ & & & \\
\hline Leptodora kindtii (Focke, 1844) & & * & $*$ & * & $*$ & $*$ & $*$ & * & & & & \\
\hline \multicolumn{13}{|l|}{ Cyclopoida } \\
\hline Mesocyclops leuckarti (Claus, 1857) & & * & $*$ & * & $*$ & * & $*$ & $* *$ & & & $*$ & * \\
\hline Thermocyclops oithonoides (Sars G.O., 1863) & $*$ & $*$ & $*$ & $*$ & $* *$ & $* *$ & $* *$ & $* *$ & $*$ & & $* *$ & \\
\hline Cyclops scutifer Sars G.O., 1863 & $* *$ & & & * & $*$ & & & $*$ & & & & \\
\hline Cyclops lacustris Sars G.O., 1862 & $* *$ & & & & & & & & & & & \\
\hline \multicolumn{13}{|l|}{ Calanoida } \\
\hline Eudiaptomus gracilis (Sars G.O., 1863) & & & & $*$ & & $*$ & & $*$ & $*$ & $*$ & $* *$ & $*$ \\
\hline Eudiaptomus graciloides (Lilljeborg, 1888) & $*$ & * & $*$ & & $*$ & & $* *$ & & & & & \\
\hline Eurytemora lacustris (Poppe, 1887) & $*$ & $*$ & & & & & $*$ & & & & & \\
\hline Heterocope appendiculata Sars G.O., 1863 & $*$ & & $*$ & & & & & & & & & \\
\hline \multicolumn{13}{|l|}{ Rotifera } \\
\hline Ascomorpha ovalis (Bergendahl, 1892) & $*$ & & $*$ & $*$ & & & $*$ & $*$ & $*$ & $*$ & & \\
\hline Asplanchna priodonta Gosse, 1850 & $* *$ & & $*$ & $*$ & $*$ & $*$ & $*$ & $* *$ & $* *$ & & $* *$ & $*$ \\
\hline Conochiloides dossuarius (Hudson, 1885) & & & & & $*$ & $*$ & $* *$ & $*$ & & & $*$ & $*$ \\
\hline Conochilus hippocrepis (Schrank, 1803) & & $* *$ & $*$ & & & & & $*$ & $*$ & & & \\
\hline Conochilus unicornis Rousselet, 1892 & $*$ & $*$ & $*$ & & & $*$ & $*$ & $*$ & $*$ & & & \\
\hline Gastropus stylifer Imhof, 1891 & $*$ & & $*$ & $*$ & & & & $*$ & $*$ & $* *$ & $*$ & $*$ \\
\hline Keratella cochlearis Gosse, 1851 & $*$ & * & $*$ & $*$ & $*$ & & $*$ & $*$ & $*$ & $* *$ & $*$ & $*$ \\
\hline Keratella irregularis (Lauterborn, 1898) & $*$ & & $*$ & * & & & $*$ & $*$ & & $*$ & & \\
\hline Keratella cochlearis tecta (Gosse, 1851) & & $*$ & $*$ & & & & $*$ & $*$ & $*$ & $*$ & $*$ & \\
\hline Polyarthra remata Skorikov, 1896 & $*$ & * & $*$ & $*$ & $*$ & $* *$ & $*$ & $*$ & $*$ & $*$ & $* *$ & $*$ \\
\hline Polyarthra vulgaris Carlin, 1943 & $*$ & $*$ & $*$ & $*$ & $*$ & & $*$ & $*$ & $*$ & $*$ & $*$ & $*$ \\
\hline Pompholyx sulcata Hudson, 1885 & $*$ & * & $*$ & * & & & $*$ & $*$ & $*$ & $* *$ & * & \\
\hline Trichocerca cylindrica (Imhof, 1891) & & & & & & & $*$ & $*$ & $*$ & $*$ & & $*$ \\
\hline
\end{tabular}

*For species with biomass $5-10 \%$

**For species constituting $10-50 \%$ of the biomass

$* * *$ For species with biomass $>50 \%$ of total zooplankton biomass

comprised up to $99 \%$ of the TN. As a result of algae uptake, there was a depletion of inorganic nitrogen in the upper water layer. The concentrations of $\mathrm{NO}_{3}{ }^{-}$ ions in the upper water layers of harmonic lakes were nearly 180 -fold lower than in the hypolimnion (Table 3). The low concentrations of $\mathrm{NO}_{3}{ }^{-}$were 
found in the epilimnion and metalimnion of mesotrophic lakes (Table 3), whereas in eutrophic lakes the low concentrations of $\mathrm{NO}_{3}{ }^{-}$were only in the epilimnion (Table 3). The average phosphorus content in phytoplankton ranged from $8.3 \%$ (mesotrophic) to $19.5 \%$ (eutrophic) of the TP content (Fig. 5A).

The average nitrogen content in zooplankton ranged from 0.5 to $1.9 \%$ of the $\mathrm{TN}$ in water (Fig. 5D), and there were no significant differences between the trophic states. However, the zooplankton was an effective sink of phosphorus in the eutrophic and mesotrophic lakes, where the average phosphorus content in zooplankton was 5-6\% of the total amount of phosphorus (Fig. 5B). In the dystrophic lakes, the average phosphorus in zooplankton was $0.74 \%$ of TP (Fig. 5B).
Primary and secondary production of plankton

There were significant differences in the GPP between the trophic conditions in the lakes $(F=4.71$; $P=0.018)$, as well as in their vertical profiles $(F=8.6 ; P=0.001)$. The average GPP was highest in the dystrophic lakes and differed significantly from that in the eutrophic and mesotrophic lakes (Fig. 6A). However, the largest differences were observed in the vertical profile. In the epilimnion, primary production was much higher than in the metalimnion and hypolimnion, including all of investigated lakes (Fig. 6B). The average ( \pm standard deviation) epilimnetic GPP in the dystrophic lakes was $4.73 \pm 2.63$ $\mathrm{gC}^{-1} \mathrm{day}^{-1}$, while in the eutrophic and mesotrophic lakes it was $1.23 \pm 1.17 \mathrm{gC}^{-1} \mathrm{day}^{-1}$ and $0.24 \pm 0.17 \mathrm{gC} \mathrm{L}^{-1} \mathrm{day}^{-1}$, respectively. The metalimnetic primary production in the dystrophic lakes was $0.15 \pm 0.17 \mathrm{gC}^{-1} \mathrm{day}^{-1}$, while in the eutrophic
Fig. 3 The canonical correspondence analysis (CCA) map of major groups of freshwater zooplankton and environmental variables (phytoplankton, nutrients, oxygen, trophic status). Sampling sites numbers 1-12 correspond to the lakes (Tables 1 and 2);

$E$ epilimnion,

$M$ metalimnion, $H$ hypolimnion

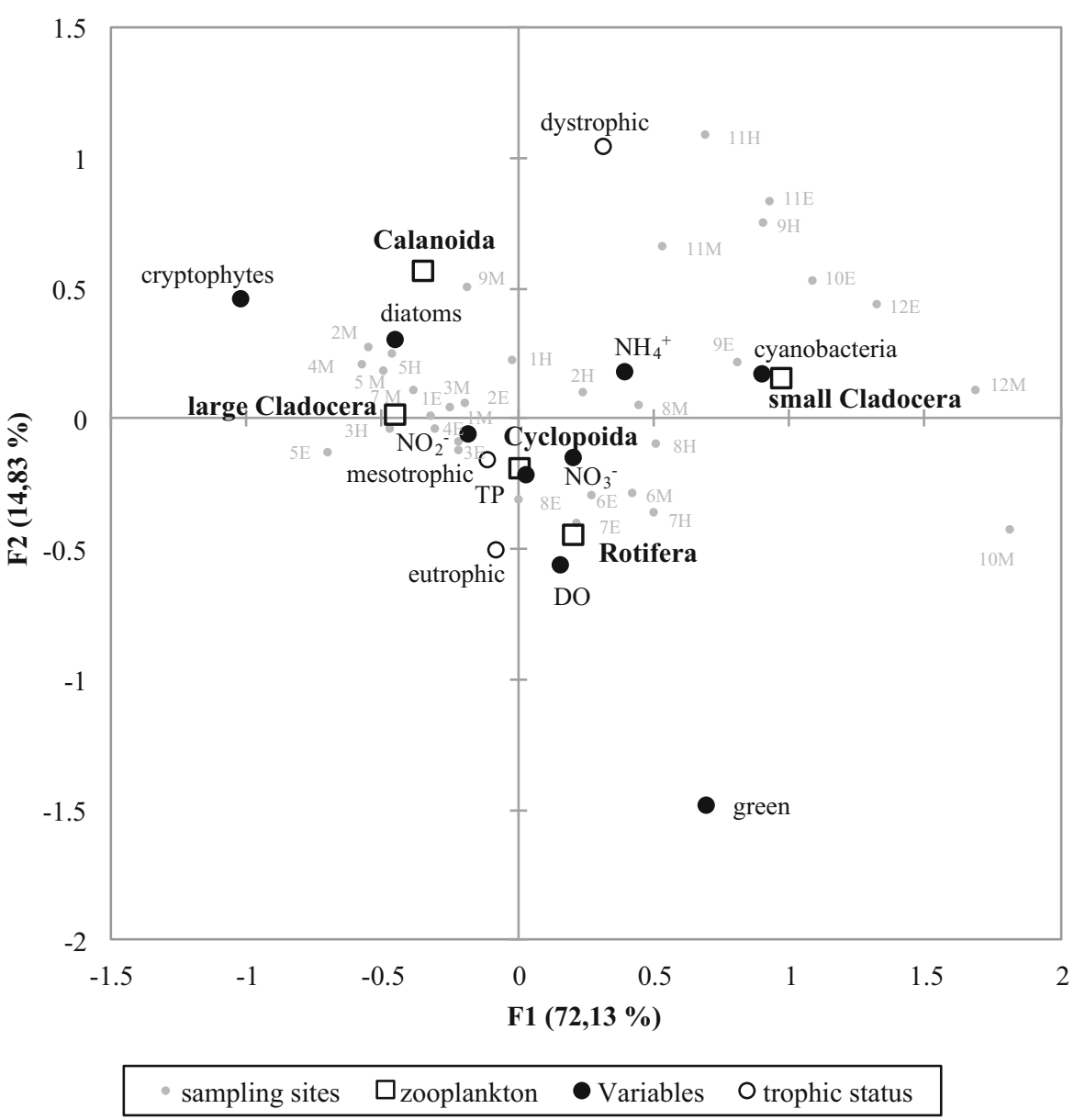



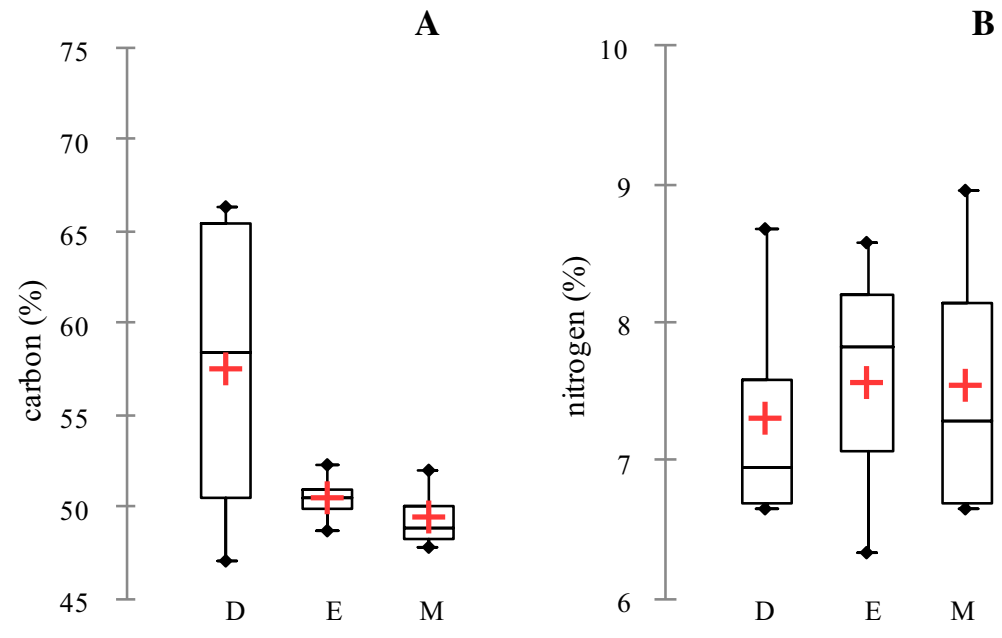

B

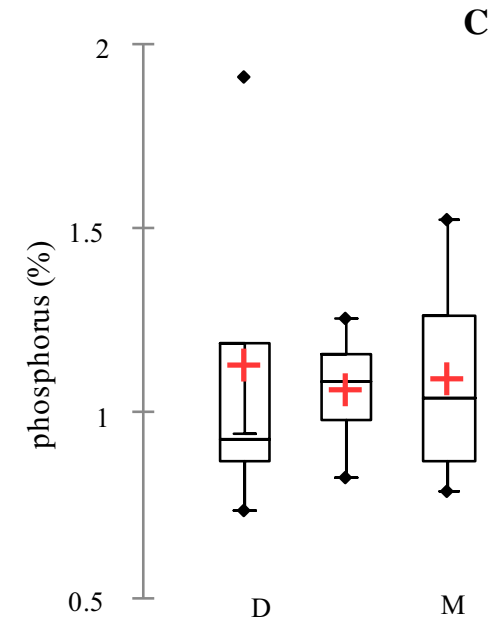

Fig. 4 Elemental composition of zooplankton (percentage share of C, N, P) in lakes with different trophic statuses. $D$ dystrophic, $E$ eutrophic, $M$ mesotrophic

and mesotrophic lakes it was $0.08 \pm 0.8 \mathrm{gC}^{-1} \mathrm{day}^{-1}$ and $0.01 \pm 0.01 \mathrm{gC}^{-1} \mathrm{day}^{-1}$, respectively.

There were no significant differences in the secondary (zooplankton) production between the lakes of different trophic conditions (Fig. 6A), as well as in the vertical profile (Fig. $6 \mathrm{~B})$. The average $( \pm \mathrm{SD}$ ) zooplankton production was $0.071 \pm 0.17 \mathrm{mgC}^{-1}$ day $^{-1}$, with a maximum of $0.91 \mathrm{mgC}^{-1} \mathrm{day}^{-1}$ in the metalimnion of eutrophic lake no. 4 , and a minimum of $0.00036 \mathrm{mgC}^{-1} \mathrm{day}^{-1}$ in the epilimnion of dystrophic lake no 10. However, there were significant differences in the hypolimnetic zooplankton production between dystrophic lakes and harmonic lakes (eutrophic and mesotrophic). The hypolimnetic secondary production in the harmonic lakes was $0.05 \pm 0.05 \mathrm{mgC}^{-1} \mathrm{day}^{-1}$, while in the dystrophic lakes it was $0.006 \pm 0.004 \mathrm{mgCl}^{-1} \mathrm{day}^{-1}$.

A comparison of primary and secondary productions in the whole water column revealed that the effectiveness of carbon transfer between phytoplankton and zooplankton ranged from $0.0005 \%$ to $0.14 \%$. The highest efficiencies of carbon transfer were in lakes no. $4(0.14 \%)$ and no. $3(0.13 \%)$, where large Cladocera dominated in the whole water column (Fig. 2). The efficiencies of carbon transfer between phytoplankton and zooplankton in the mesotrophic and eutrophic lakes were $0.068 \%$ and $0.048 \%$, respectively (Fig. 7). However, the low efficiency of carbon transfer between phytoplankton and zooplankton $(0.006 \%)$ was noted in one eutrophic lake (no. 5) with the highest share of cyanobacteria (Fig. 1). The lowest efficiency of carbon transfer was observed in the dystrophic lakes, where, on average, only $0.001 \%$ of organic carbon production by phytoplankton was incorporated into new biomass of zooplankton (Fig. 7).

\section{Discussion}

The results of our study confirm that eutrophication and humification decrease the efficiency of the transfer of matter between phytoplankton and zooplankton. The lowest efficiency was observed in dystrophic lakes, where only $0.001 \%$ of organic carbon production of phytoplankton was incorporated into new biomass of zooplankton. These lakes were characterized by high biomass of phytoplankton, which was similar to that of the hypertrophic reservoir with cyanobacterial blooms (Grabowska \& Wołowski 2014; Górniak \& Karpowicz, 2014). The high biomass of phytoplankton was well documented for the dystrophic lakes of Wigry National Park (Karpowicz \& Ejsmont-Karabin, 2018), with expansive development of flagellate Gonyostomum semen (Pęczuła et al., 2018). This flagellate was also dominant in all the studied dystrophic lakes, contributing to $92.7 \%$ of the PB. G. semen has been drawing much attention for many years due to frequent blooms observed in humic lakes in Northern Europe (Korneva, 2000), and 

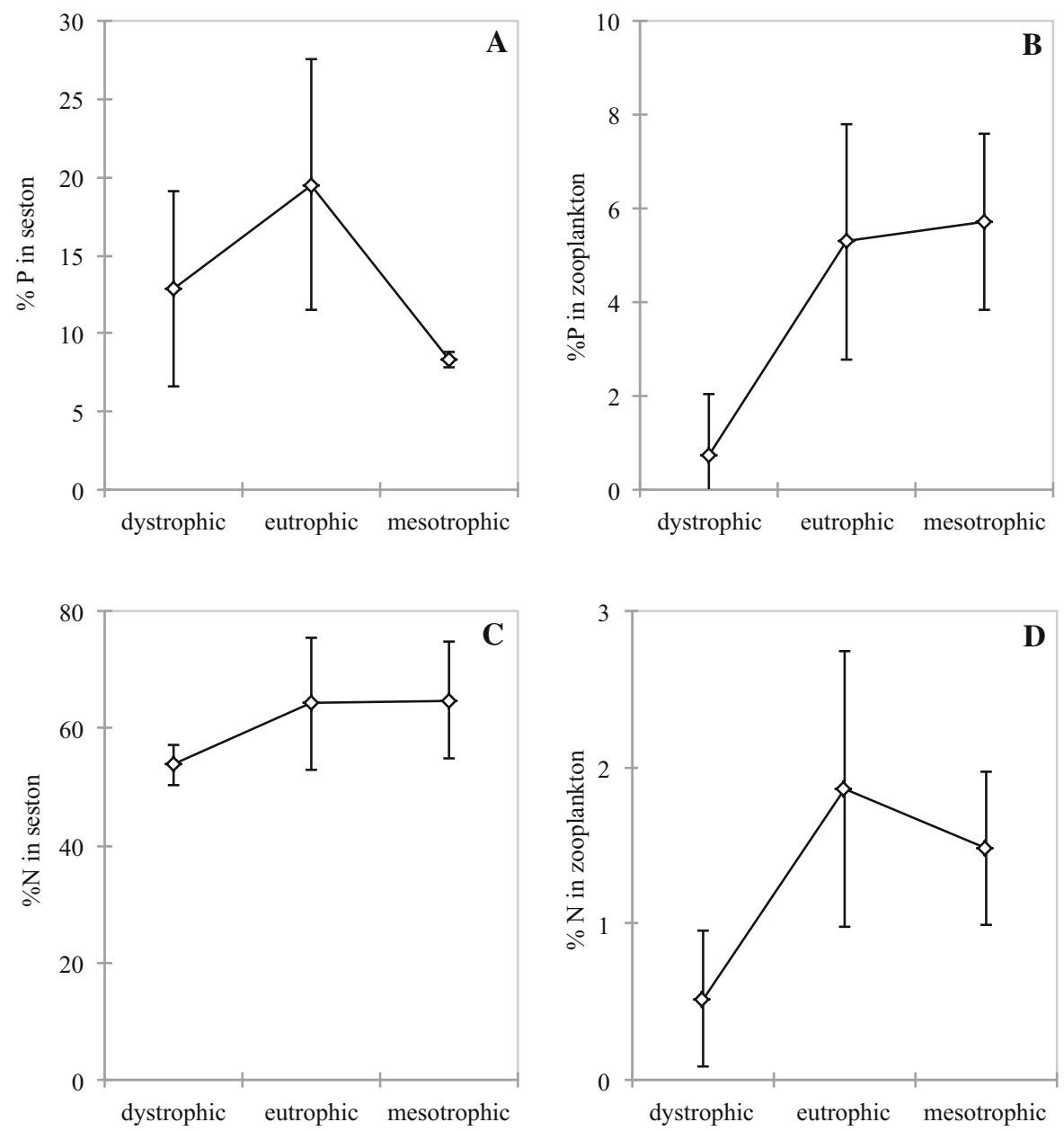

Fig. 5 The mean percentage $( \pm \mathrm{SD})$ of phosphorus and nitrogen in zooplankton and seston compared to the total amount of phosphorus in the water

recently, also in Poland, Latvia, and Lithuania (Karosiene et al., 2014). Although this species is generally inedible for most zooplankton species due to its large body size $(50-70 \mu \mathrm{m})$ and the presence of trichocysts, the research suggests that $G$. semen could be grazed by large zooplankton (Asplanchna priodonta, Daphnia pulicaria, Holopedium gibberum, and Eudiaptomus gracilis) (Williamson et al., 1996; Lebret et al., 2012; Johansson et al., 2013; Pęczuła et al., 2018). These zooplankton species are also common components of humic lakes, which suggests that some part of the matter and energy accumulated in Gonyostomum can be transferred to higher trophic levels. However, during Gonyostomum blooms small zooplankton dominate over large zooplankton species, which strongly reduces the importance of
Gonyostomum as a food resource (Johansson et al., 2013). The high biomass of G. semen in the studied dystrophic lakes could be a reason of the very low efficiency of carbon transfer between phytoplankton and zooplankton.

Literature data from more than 600 lakes also confirmed that bacteria and phytoplankton production is higher in humic lakes than in harmonic lakes (Nürnberg \& Shaw, 1999). The results of this study also indicate that in the dystrophic lakes, high biomass of phytoplankton contrasts with low biomass of zooplankton, which results in a very low efficiency of transfer of matter between phytoplankton and zooplankton. Noteworthy is that in humic lakes, the large amount of food resources for crustacean zooplankton and low fish pressure do not lead to the 
Fig. 6 Differences in gross primary production (GPP) and secondary (zooplankton) production $\left(\mathrm{mgC}^{-1} \mathrm{day}^{-1}\right)$ in different trophic conditions (A) and in vertical profiles

(B) presented by leastsquares means (LS) and standard deviation (solid vertical lines for GPP, and dashed vertical lines for zooplankton production)
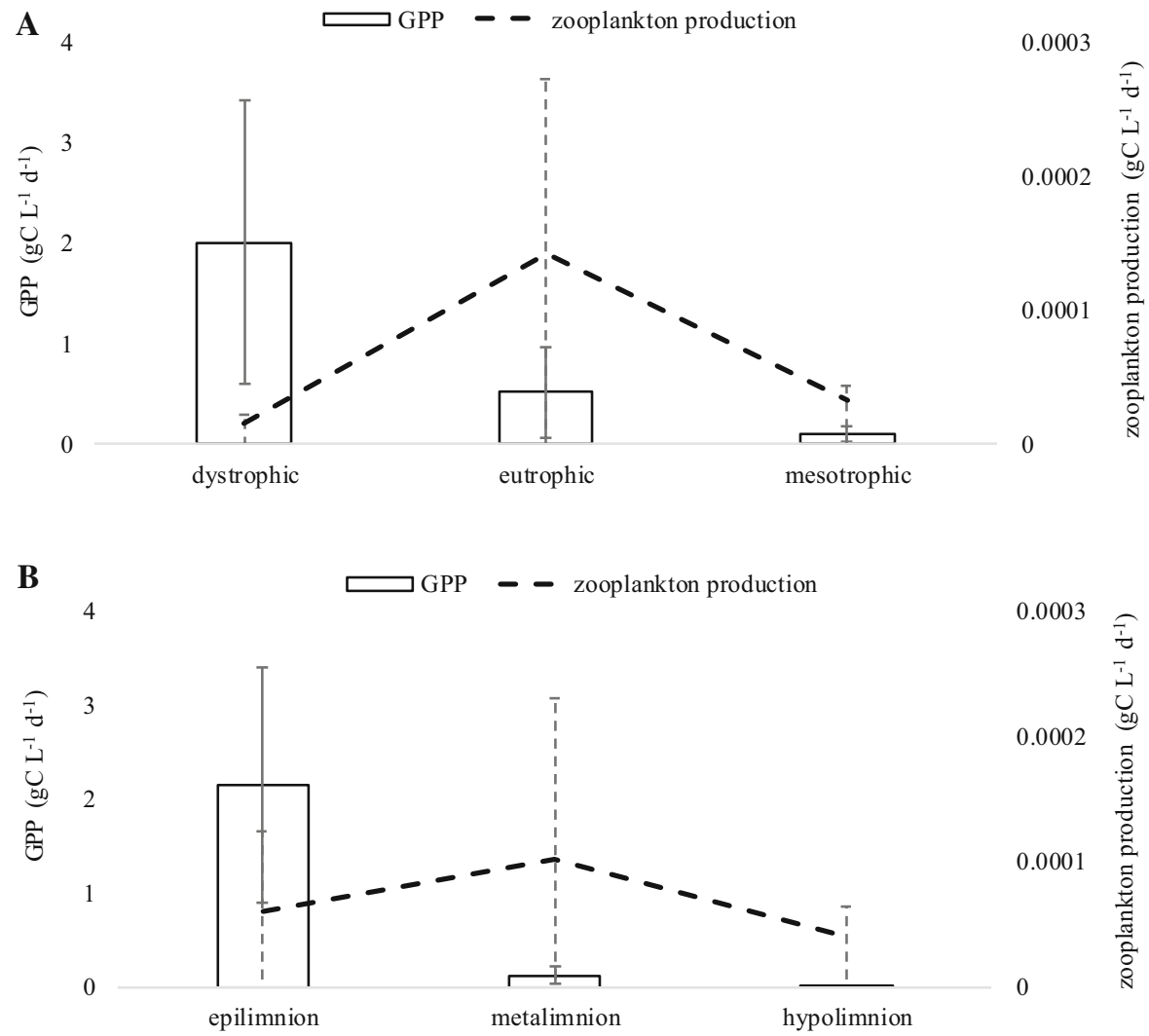

massive development of large-bodied zooplankton. The factors that prevent the development of largebodied crustaceans in humic lakes are still unclear. Some authors suggest that humic stress connected to the high concentrations of humic substances and DOC could constrain zooplankton development (Robidoux et al., 2015). Other researchers believe that food quality for zooplankton in humic lakes is low (Taipale et al., 2016). Our previous results suggest that the sharp changes in temperature and low oxygen concentration in humic lakes are the main factors which reduce the zooplankton biomass and can promote the development of phytoplankton (Karpowicz \& Ejsmont-Karabin, 2018). This finding is also supported by our current data indicating that the high biomass of zooplankton was found in Lake Suchar Wielki (no. 12), which has a deep and oxygenated epilimnion. Nevertheless, the common statement that dystrophic lakes are unproductive (Berggren et al., 2009; Kostrzewska-Szlakowska \& Jasser, 2011) should be revised. Some authors have more precisely specified that humic lakes are unproductive from a fishery point of view (Rask et al., 1995; Finstad et al., 2014). In

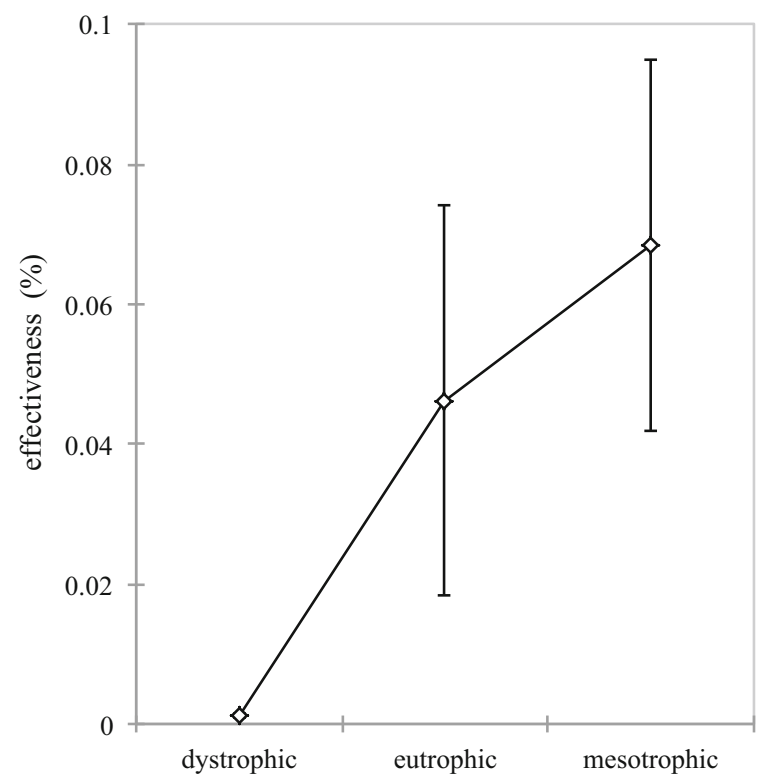

Fig. 7 Effectiveness (\%) of carbon transfer between phytoplankton and zooplankton in lakes with different trophic statuses presented by least-squares means (LS) with standard deviation 
regard to primary production, our data show that humic lakes are highly productive (Fig. 6), but the transfer of matter between phytoplankton and zooplankton is very ineffective (Fig. 7).

The highest efficiency of the transfer of matter was in the mesotrophic lakes due to a higher hypolimnetic zooplankton production. The well-oxygenated hypolimnion zones promote a large species richness of crustacean zooplankton and create a favourable habitat for cold-water species with high environmental requirements (Karpowicz et al., 2019a). We found a high species richness and large size variability of zooplankton in the water column of the mesotrophic lakes. The well-oxygenated hypolimnion allowed the vertical niche segregation of Daphnia species, where 3-4 species were found in each lake. Different species of Daphnia could occupy different niches if they differ from each other by life-history strategies, habitat preferences, behaviour, morphology, body size, filtration rate, and vulnerability to predation (Brzeziński et al., 2012). The high species richness of the Daphnia genus in Lake Wigry has been well known for a long time (Kamiński, 1999; Karpowicz et al., 2019a). The migration of large species to deeper layers creates favourable conditions for small species in the upper layer (Karpowicz \& Ejsmont-Karabin, 2017). This can promote the effective transfer of energy and matter to higher trophic levels because it critically depends on the size structure of the zooplankton (Rykaczewski \& Checkley, 2008; Beaugrand et al., 2010). The large size variability of zooplankton in the water column also promotes niche partitioning of predators (Ye et al., 2013), which makes the transfer of energy throughout the whole lake food web more efficient. The lower water layers in the mesotrophic lakes were inhabited by large zooplankton, among which five relict and rare crustacean species occurred (Eurytemora lacustris, Heterocope appendiculata, Cyclops lacustris, Bythotrephes brevimanus, and Daphnia longiremis). These cold-adapted species spread over Europe, along with glaciers, during the last ice age and were able to survive only in deep lakes with welloxygenated hypolimnion (Spikkeland et al., 2016; Karpowicz \& Kalinowska, 2018). The high habitat requirements make them a very useful indicator of good ecological status in lakes and low trophic conditions (Ejsmont-Karabin \& Karabin, 2013; Ochocka \& Pasztaleniec, 2016). The results of our study revealed a high zooplankton production in deeper layers of the mesotrophic lakes, which, together with large species richness, promotes the effective transfer of matter in the pelagic food web.

Recent research suggests that eutrophication and climate change are two processes that may promote the proliferation and expansion of harmful cyanobacterial blooms (O'Neil et al., 2012). Our results indicate that the eutrophication process also causes a decrease in the efficiency of carbon transfer between phytoplankton and zooplankton, but not so much as the humification process. We have found a similar efficiency of carbon transfer between phytoplankton and zooplankton in the mesotrophic and eutrophic lakes, which could be attributed to a small share of cyanobacteria in our lakes. The dominance of cyanobacteria was recorded only in Lake Długie Wigierskie (no. 5), which had a very low efficiency of carbon transfer between the phytoplankton and zooplankton. Cyanobacteria generally have many deleterious effects on zooplankton grazing, via production of toxins (Ferrão-Filho \& Kozlowsky-Suzuki, 2011; Holland \& Kinnear, 2013; Mantzouki et al., 2018), low nutritional value (Vanni \& Lampert, 1992; Sikora et al., 2016; Feniova et al., 2018), and filamentous colony structure which inhibit filtration processes (Gliwicz, 1990; Sikora \& Dawidowicz, 2014). This indicates that cyanobacteria and/or inedible algae are the main factors reducing the efficiency of the transfer of matter in pelagic food webs.

One of the general paradigms of ecology is that only $10 \%$ of energy and matter pass to the next trophic level (Lindeman, 1942; Gladyshev et al., 2011). The primary producers convert inorganic carbon into organic carbon, which is incorporated into new biomass at higher trophic levels. Therefore, the production and effectiveness of matter transfer are frequently measured in carbon mass units (Pauly \& Christensen, 1995; Schulz et al., 2004). The transfer efficiency in marine ecosystems ranged between 2 and 24\% (Pauly \& Christensen, 1995) and is similar to that in lakes where the transfer efficiency between phytoplankton and zooplankton ranges between 1 and $30 \%$ (Lacroix et al., 1999). However, the results of our study revealed much lower carbon transfer efficiency between phytoplankton and zooplankton in lakes with different trophic statuses, which varied between $0.0005 \%$ and $0.14 \%$. Such very low efficiency in the algal-based pathway may be attributed to the dominance of large inedible algae in seston during the peak 
of summer stagnation. However, more accurate methods to measure the efficiency of carbon transfer in planktonic food webs suggest that only $0.1 \%$ of the carbon produced by the phytoplankton is incorporated into zooplankton (Sherr \& Sherr, 1987; Havens et al., 2000). Measurements of carbon transfer in algal and bacterial food webs revealed the same low efficiencies for both pathways (Ducklow et al., 1996; Koshikawa et al., 1996). This suggests that the effectiveness of carbon transfer through planktonic freshwater food webs is much lower than the theoretical $10 \%$.

The results of our study showed that plankton communities are a key component of the nutrient cycle in freshwater food webs. Phytoplankton were a very effective sink of nitrogen and phosphorus. In mesotrophic lakes, up to $99 \%$ of TN was sequestrated in phytoplankton, thus causing a depletion of inorganic nitrogen in the upper water layer. Phytoplankton have a high demand for nitrogen because they contain intracellular nitrogen in many forms, e.g. nitrate, ammonium, amino acids, protein, RNA, and pigments (Dortch, 1982). According to the Lagrangian model, algae acquires nutrients at the bottom of the habitat while it grows in shallower waters, and when their nutrient quota falls below a certain threshold, the cells start to sink (Grover, 2017). Field studies revealed that a deep chlorophyll layer is a common phenomenon in clear water lakes, as a result of a nutrient shortage in the epilimnion during summer stagnation (Camacho, 2006; Karpowicz \& Ejsmont-Karabin, 2017). Our results indicated that a shortage of dissolved nitrogen in the epilimnion could be the main factor for formation of the deep chlorophyll layer in mesotrophic lakes. Also, mesocosm experiments confirmed that nitrogen was effectively accumulated by phytoplankton (Karpowicz et al., 2019b) and sequestration of nitrogen by phytoplankton was much higher than remineralization by zooplankton.

The results of our study also suggest that the zooplankton is an effective sink of phosphorus. However, zooplankton could act simultaneously as a phosphorus sink by incorporating $\mathrm{P}$ and as a source of phosphorus, by excretion of phosphate and organic phosphorus (e.g. Lampert et al., 1986; den Oude \& Gulati, 1988; Lyche et al., 1996). This dualism in the functional role of zooplankton is very important for the nutrient cycle in lakes. The threshold elemental ratio model, which is a principal concept in ecological stoichiometry, assumes that the element in the least supply is assimilated with maximum efficiency (Hessen et al., 2013). The excretion of phosphorus by Daphnia could drop to zero when there is low phosphorus content in algae (i.e. C:P ratio ranging from 320 to 430) (Olsen et al., 1986; Sterner et al., 1998). Therefore, low $P$ content in algae, together with high demand for P by Daphnia, underlines the role of zooplankton as a sink of phosphorus. Finally, zooplankton also contributes to the translocation of nutrients within the water column (Karpowicz \& Ejsmont-Karabin, 2017; Sługocki \& Czerniawski, 2018), and its importance in nutrient cycles increases with lake size (Fee et al., 1994).

\section{Conclusions}

Our results indicated that the effectiveness of carbon transfer between phytoplankton and zooplankton varied from $0.0005 \%$ to $0.14 \%$, which is much lower than the theoretical $10 \%$. However, the highest efficiency of transfer of matter was in mesotrophic lakes due to the higher hypolimnetic zooplankton production. The well-oxygenated hypolimnion zones increases zooplankton species richness and creates a favourable habitat for cold-water species with high environmental requirements. The lowest efficiency was noted in dystrophic lakes, where only $0.001 \%$ of organic carbon production of phytoplankton was incorporated into new biomass of zooplankton. Our results indicated that cyanobacteria and/or inedible algae (G. semen) are the main factors reducing the efficiency of the transfer of matter in pelagic food webs.

The results of our study showed that plankton communities are the key component of the nutrient cycle in the freshwater food web. The phytoplankton was a very effective sink of nitrogen $(62.2 \pm 17.8 \%)$ and phosphorus $(13.2 \pm 12.4 \%)$. However, in mesotrophic lakes, up to $99 \%$ of $\mathrm{TN}$ was sequestrated in phytoplankton, and as a result, there was a depletion of inorganic nitrogen in the upper water layer. The results of this study also suggest that zooplankton is an effective sink of phosphorus in eutrophic and mesotrophic lakes, where its average content in zooplankton reaches up to $5-6 \%$ of TP.

Acknowledgements This research was supported by the Polish National Science Centre (2017/01/X/NZ8/01151). We 
thank editor Dr. Gideon Gal and anonymous reviewers for their valuable feedback. The authors are thankful Dr. Andrew Dzialowski for improving the language of the manuscript.

Conflict of Interest: The authors declare that they have no conflict of interest.

Open Access This article is licensed under a Creative Commons Attribution 4.0 International License, which permits use, sharing, adaptation, distribution and reproduction in any medium or format, as long as you give appropriate credit to the original author(s) and the source, provide a link to the Creative Commons licence, and indicate if changes were made. The images or other third party material in this article are included in the article's Creative Commons licence, unless indicated otherwise in a credit line to the material. If material is not included in the article's Creative Commons licence and your intended use is not permitted by statutory regulation or exceeds the permitted use, you will need to obtain permission directly from the copyright holder. To view a copy of this licence, visit http://creativecommons.org/licenses/by/4.0/.

\section{References}

Alimov, A. F., 1989. An Introduction to Production Hydrobiology. Gidrometeoizdat, Leningrad.

Beaugrand, G., M. Edwards \& L. Legendre, 2010. Marine biodiversity, ecosystem functioning, and carbon cycles. Proceedings of the National Academy of Sciences of the United States of America 107: 10120-10124.

Berggren, M., H. Laudon \& M. Jansson, 2009. Aging of allochthonous organic carbon regulates bacterial production in unproductive boreal lakes. Limnology and Oceanography 54: 1333-1342.

Beutler, M., K. H. Wiltshire, B. Meyer, C. Moldaenke, C. Lüring, M. Meyerhöfer, U.-P. Hansen \& H. Dau, 2002. A fluorometric method for the differentiation of algal populations in vivo and in situ. Photosynthesis Research 72: 39-53.

Błędzki, L. A. \& J. I. Rybak, 2016. Freshwater Crustacean Zooplankton of Europe. Springer Nature, Switzerland.

Bottrell, H. H., A. Duncan, Z. M. Gliwicz, E. Grygierek, A. Herzig, A. Hillbricht-Ilkowska, H. Kurasawa, P. Larsson \& T. Węgleńska, 1976. A review of some problems in zooplankton production studies. Norwegian Journal of Zoology 24: 419-456.

Boyd, C. E., 2015. Phosphorus. In: Water Quality. Springer, Cham.

Brett, M. T. \& D. C. Müller-Navarra, 1997. The role of highly unsaturated fatty acids in aquatic food web processes. Freshwater Biology 38: 483-499.

Brzeziński, T., J. Fronk, J. Trzcińska-Danielewicz \& P. Dawidowicz, 2012. Interspecific hybridization in sympatric species of Daphnia inhabiting lakes in north-eastern Poland. Oceanological and Hydrobiological Studies 41: $1-6$.
Camacho, A., 2006. On the occurrence and ecological features of deep chlorophyll maxima (DCM) in Spanish stratified lakes. Limnetica 25: 453-478.

Carlson, R. E., 1977. A trophic state index for lakes. Limnology and Oceanography 22: 361-369.

den Oude, P. J. \& R. D. Gulati, 1988. Phosphorus and nitrogen excretion rates of zooplankton from the eutrophic Loosdrecht lakes, with notes on other $\mathrm{P}$ sources for phytoplankton requirements. Hydrobiologia 169: 379-390.

Dortch, Q., 1982. Effect of growth conditions on accumulation of internal nitrate, ammonium, amino acids, and protein in three marine diatoms. Journal of Experimental Marine Biology and Ecology 61: 242-264.

Ducklow, H. W., D. A. Purdie, P. J. Williams \& J. M. Davies, 1986. Bacterioplankton: a sink for carbon in a coastal marine plankton community. Science 232: 865-867.

Ejsmont-Karabin, J., 1998. Empirical equations for biomass calculation of planktonic rotifers. Polish Archives of Hydrobiology 45: 513-522.

Ejsmont-Karabin, J. \& A. Karabin, 2013. The suitability of zooplankton as lake ecosystem indicator: crustacean trophic state index. Polish Journal of Ecology 61: 561-573.

Fee, E. J., R. E. Hecky, S. E. M. Kasian \& D. R. Cruikshank, 1996. Effects of lake size, water clarity, and climatic variability on mixing depths in Canadian Shield lakes. Limnology and Oceanography 41: 912-920.

Feniova, I., P. Dawidowicz, J. Ejsmont-Karabin, M. I. Gladyshev, K. Kalinowska, M. Karpowicz, I. KostrzewskaSzlakowska, N. Majsak, V. Petrosyan, V. Razlutskij, M. Rzepecki, N. Sushchik \& A. R. Dzialowski, 2018. Effects of zebra mussels on cladoceran communities under eutrophic conditions. Hydrobiologia 822: 37-54.

Feniova, I., E. Sakharova, M. Karpowicz, M. I. Gladyshev, N. N. Sushchik, P. Dawidowicz, Z. Gorelysheva, A. Górniak, Y. Stroinov \& A. Dzialowski, 2019. Direct and indirect impacts of fish on crustacean zooplankton in experimental mesocosms. Water 11: 2090.

Ferrão-Filho, A. D. S. \& B. Kozlowsky-Suzuki, 2011. Cyanotoxins: bioaccumulation and effects on aquatic animals. Marine Drugs 9: 2729-2772.

Finstad, A. G., I. P. Helland, O. Ugedal, T. Hesthagen \& D. O. Hessen, 2014. Unimodal response of fish yield to dissolved organic carbon. Ecology Letters 17: 36-43.

Gaevsky, N. A., V. I. Kolmakov, V. A. Popelnitsky, V. M. Gold \& O. P. Dubovskaya, 2000. Evaluation of the effect of light intensity on the measurement of the photosynthetic rate in plankton microalgae by the chlorophyll fluorescence method. Russian Journal of Plant Physiology 47: 820-825.

Gladyshev, M. I., N. N. Sushchik, O. V. Anishchenko, O. N. Makhutova, V. I. Kolmakov, G. S. Kalachova, A. A. Kolmakova \& O. P. Dubovskaya, 2011. Efficiency of transfer of essential polyunsaturated fatty acids versus organic carbon from producers to consumers in a eutrophic reservoir. Oecologia 165: 521-531.

Gliwicz, Z. M., 1990. Why do Cladocerans fail to control algal blooms? Hydrobiologia 200: 83-97.

Górniak, A., 2017. A new version of the Hydrochemical Dystrophy Index to evaluate dystrophy in lakes. Ecological Indicators 78: 566-573.

Górniak, A. \& M. Karpowicz, 2014. Development of crustacean plankton in a shallow, polyhumic reservoir in the first 
20 years after impoundment (northeast Poland). Inland Waters 4: 311-318.

Grabowska, M. \& K. Wołowski, 2014. Development of Trachelomonas species (Euglenophyta) during blooming of Planktothrix agardhii (Cyanoprokaryota). Annales de Limnologie - International Journal of Limnology 50: 49-57.

Gregor, J. \& B. Maršálek, 2004. Freshwater phytoplankton quantification by chlorophyll a: a comparative study of in vitro, in vivo and in situ methods. Water Research 38: 517-522.

Grover, J. P., 2017. Sink or swim? Vertical movement and nutrient storage in phytoplankton. Journal of Theoretical Biology 432: 38-48.

Haney, J. F., 1987. Field studies on zooplankton-cyanobacteria interactions. New Zealand Journal of Marine and Freshwater Research 21: 465-475.

Hart, R. C. \& E. A. Bychek, 2011. Body size in freshwater planktonic crustaceans: an overview of extrinsic determinants and modifying influences of biotic interactions. Hydrobiologia 668: 61-108.

Havens, K. E., K. A. Work \& T. L. East, 2000. Relative efficiencies of carbon transfer from bacteria and algae to zooplankton in a subtropical lake. Journal of Plankton Research 22: 1801-1809.

Hessen, D. O., J. J. Elser, R. W. Sterner \& J. Urabe, 2013. Ecological stoichiometry: an elementary approach using basic principles. Limnology and Oceanography 58: 2219-2236.

Hillebrand, H., C.-D. Dürselen, D. Kirschtel, U. Pollingher \& T. Zohary, 1999. Biovolume calculation for pelagic and benthic microalgae. Journal of Phycology 35: 403-424.

Holland, A. \& S. Kinnear, 2013. Interpreting the possible ecological role(s) of cyanotoxins: compounds for competitive advantage and/or physiological aide? Marine Drugs 11: 2239-2258.

Ishimaru, T., M. Mimuro \& Y. Fujita, 1985. Estimation of phytoplankton photosynthesis using a fluorescence induction technique. Journal of Plankton Research 7: 679-689.

Johansson, K. S. L., T. Vrede, K. Lebret \& R. K. Johnson, 2013. Zooplankton feeding on the nuisance Flagellate Gonyostomum semen. PLoS ONE 8: e62557.

Kamiński, M., 1999. Lake Wigry, the lake "adopted" by international association of theoretical and applied limnology (SIL "Lake Adoption" Project). Polish Journal of Ecology 47: 215-224.

Karosiene, J., J. Kasperovičiene, J. Koreiviene \& I. Vitonyte, 2014. Assessment of the vulnerability of Lithuanian lakes to expansion of Gonyostomum semen (Raphidophyceae). Limnologica 45: 7-15.

Karpowicz, M. \& J. Ejsmont-Karabin, 2017. Effect of metalimnetic gradient on phytoplankton and zooplankton (Rotifera, Crustacea) communities in different trophic conditions. Environmental Monitoring and Assessment 189: 367.

Karpowicz, M. \& J. Ejsmont-Karabin, 2018. Influence of environmental factors on vertical distribution of zooplankton communities in humic lakes. International Journal of Limnology: Annales de Limnologie 54: 17.

Karpowicz, M. \& K. Kalinowska, 2018. Vertical distribution of the relic species Eurytemora lacustris (Copepoda,
Calanoida) in stratified mesotrophic lakes. Biologia 73: 1197-1204.

Karpowicz, M., J. Ejsmont-Karabin, A. Więcko, A. Górniak \& A. Cudowski, 2019. A place in space - the horizontal vs vertical factors that influence zooplankton (Rotifera, Crustacea) communities in a mesotrophic lake. Journal of Limnology 78: 243-258.

Karpowicza, M., I. Feniova, M. I. Gladyshev, J. EjsmontKarabin, A. Górniaka, P. Zieliński, P. Dawidowicz, A. A. Kolmakova \& A. R. Dzialowski, 2019. The stoichiometric ratios $(\mathrm{C}: \mathrm{N}: \mathrm{P})$ in a pelagic food web under experimental conditions. Limnologica 77: 125690.

Korneva, L. G., 2014. Invasions of alien species of planktonic microalgae into the fresh waters of Holarctic (Review). Russian Journal of Biological Invasions 5: 65-81.

Koshikawa, H., H. Shigeki, M. Watanabe, K. Sato \& K. Akehatu, 1996. Relative contribution of bacterial and photosynthetic production to metazooplankton as carbon sources. Journal of Plankton Research 18: 2269-2281.

Kostrzewska-Szlakowksa, I. \& I. Jasser, 2011. Black box: what do we know about humic lakes? Polish Journal of Ecology 59: 647-664.

Kring, S. A., S. E. Figary, G. L. Boyer, S. B. Watson \& M. R. Twiss, 2014. Rapid in situ measures of phytoplankton communities using the bbe FluoroProbe: evaluation of spectral calibration, instrument intercompatibility, and performance range. Canadian Journal of Fisheries and Aquatic Sciences 71: 1087-1095.

Lacroix, G., F. Lescher-Moutoue \& A. Bertolo, 1999. Biomass and production of plankton in shallow and deep lakes: are there general patterns? International Journal of Limnology: Annales de Limnologie 35: 111-122.

Lampert, W., W. Fleckner, H. Rai \& B. E. Taylor, 1986. Phytoplankton control by grazing zooplankton: a study on the spring clearwater phase. Limnology and Oceanography 31: 478-490.

Lebret, K., M. F. Fernandez, C. H. C. Hagman, K. Rengefors \& L.-A. Hansson, 2012. Grazing resistance allows bloom formation and may explain invasion success of Gonyostomum semen. Limnology and Oceanography 57: 727-734.

Lindeman, R. L., 1942. The trophic-dynamic aspect of ecology. Ecology 23: 399-418.

Lyche, A., T. Anderson, K. Christoffersen, D. O. Hessen, P. H. Berger-Hansen \& A. Klysner, 1996. Mesocosm tracer studies. 1. Zooplankton as sources and sinks in the pelagic phosphorus cycle of a mesotrophic lake Limnology and Oceanography 41: 460-474.

Mantzouki, E., M. Lürling, J. Fastner, L. de Senerpont Domis, E. Wilk-Woźniak, J. Koreiviene, et al., 2018. Temperature effects explain continental scale distribution of cyanobacterial toxins. Toxins 10: 156.

Murphy, J. \& J. P. Riley, 1962. A modified single solution method for the determination of phosphate in natural waters. Analytica Chimica Acta 27: 31-36.

Neal, C., M. Neal \& H. Wickham, 2000. Phosphate measurement in natural waters: two examples of analytical problems associated with silica interference using phosphomolybdic acid methodologies. Science of the Total Environment 251(252): 513-542. 
Nürnberg, G. K. \& M. Shaw, 1999. Productivity of clear and humic lakes: nutrients, phytoplankton, bacteria. Hydrobiologia 382: 97-112.

O’Neil, J. M., T. W. Davis, M. A. Burford \& C. J. Gobler, 2012. The rise of harmful cyanobacteria blooms: the potential roles of eutrophication and climate change. Harmful Algae 14: 313-334.

Ochocka, A. \& A. Pasztaleniec, 2016. Sensitivity of plankton indices to lake trophic conditions. Environmental Monitoring and Assessment 188: 622.

Olsen, Y., K. M. Varum \& A. Jensen, 1986. Some characteristics of the carbon compounds released by Daphnia. Journal of Plankton Research 8: 505-517.

Pauly, D. \& V. Christensen, 1995. Primary production required to sustain global fisheries. Nature 374: 255-257.

Pęczuła, W., M. Grabowska, P. Zieliński, M. Karpowicz \& M. Danilczyk, 2018. Vertical distribution of expansive, bloom-forming algae Gonyostomum semen vs. plankton community and water chemistry in four small humic lakes. Knowledge and Management of Aquatic Ecosystems 419: 28.

Rask, M., J. Mannio, M. Forsius, M. Posch \& P. J. Vuorinen, 1995. How many fish populations in Finland are affected by acid precipitation? Environmental Biology of Fishes 42: 51-63.

Robidoux, M., P. del Giorgio \& A. Derry, 2015. Effects of humic stress on the zooplankton from clear and DOC-rich lakes. Freshwater Biology 60: 1263-1278.

Rykaczewski, R. R. \& D. M. Checkley, 2008. Influence of ocean winds on the pelagic ecosystem in upwelling regions. Proceedings of the National Academy of Sciences of the United States of America 105: 1965-1970.

Schulz, M., R. Koschel, C. Reese \& T. Mehner, 2004. Pelagic trophic transfer efficiency in an oligotrophic, dimictic deep lake (Lake Stechlin, Germany) and its relation to fisheries yield. Limnologica 34: 264-273.

Sherr, E. B. \& B. F. Sherr, 1987. High rates of consumption of bacteria by pelagic ciliates. Nature 325: 710-711.

Sikora, A. \& P. Dawidowicz, 2014. Do the presence of filamentous cyanobacteria and an elevated temperature favor small-bodied Daphnia in interspecific competitive interactions? Fundamental and Applied Limnology 185: 307-314.

Sikora, A. B., Th Petzoldt, P. Dawidowicz \& E. von Elert, 2016. Demands of eicosapentaenoic acid (EPA) in Daphnia: are they dependent on body size? Oecologia 182: 405-417.

Sługocki, Ł. \& R. Czerniawski, 2018. Trophic state (TSISD) and mixing type significantly influence pelagic zooplankton biodiversity in temperate lakes (NW Poland). PeerJ 6: e5731.
Spikkeland, I., B. Kinsten, G. Kjellberg, J. P. Nilssen \& R. Väinölä, 2016. The aquatic glacial relict fauna of Norway an of distribution and conservation status. Fauna norvegica 36: 51-65.

Sterner, R. W. \& J. J. Elser, 2002. Ecological stoichiometry: The biology of elements from molecules to the biosphere. Princeton University Press, Princeton.

Sterner, R. W., J. Clasen, W. Lampert \& T. Weisse, 1998. Carbon:phosphorus stoichiometry and food chain production. Ecology Letters 1: 146-150.

Stockwell, J. D. \& O. E. Johansson, 1997. Temperature-dependent allometric models to estimate zooplankton production in temperate freshwater lakes. Canadian Journal of Fisheries and Aquatic Sciences 54: 2350-2360.

Taipale, S. J., K. Vuorio, U. Strandberg, K. K. Kahilainen, M. Järvinen, M. Hiltunen, E. Peltomaa \& P. Kankaala, 2016. Lake eutrophication and brownification downgrade availability and transfer of essential fatty acids for human consumption. Environment International 96: 156-166.

Utermöhl, H., 1958. Zur Vervollkommnung der quantitativen Phytoplankton-Methodik. Verhandlungen der Internationalen Vereinigung für Theoretische und Angewandte Limnologie 9: 1-39.

Vanni, M. J. \& W. Lampert, 1992. Food quality effects on life history traits and fitness in the generalist herbivore Daphnia. Oecologia 92: 48-57.

Vitousek, P. \& R. Howarth, 1991. Nitrogen limitation on land and in the sea: how can it occur? Biogeochemistry 13: 87-115.

Williamson, C. E., R. W. Sanders, R. E. Moeller \& P. L. Stutzman, 1996. Utilization of subsurface food resources for zooplankton reproduction: implications for diel vertical migration theory. Limnology and Oceanography 41: 224-233.

Ye, L., C. Y. Chang, C. García-Comas, G.-C. Gong \& C. H. Hsieh, 2013. Increasing zooplankton size diversity enhances the strength of top-down control on phytoplankton through diet niche partitioning. Journal of Animal Ecology 82: 1052-1061.

Yu, C., C. Li, T. Wang, M. Zhang \& J. Xu, 2018. Combined effects of experimental warming and eutrophication on phytoplankton dynamics and nitrogen uptake. Water 10: 1057.

Publisher's Note Springer Nature remains neutral with regard to jurisdictional claims in published maps and institutional affiliations. 